\title{
Pappocricetodontinae (Rodentia, Muridae) from the Paleogene of south-east Serbia
}

\author{
Hans de Bruijn ${ }^{1} \cdot$ Zoran Marković $^{2} \cdot$ Wilma Wessels $^{1} \cdot$ Andrew A. van de Weerd $^{1}$ \\ Received: 1 February 2018 /Revised: 28 April 2018 / Accepted: 19 June 2018 /Published online: 11 September 2018 \\ (C) The Author(s) 2018
}

\begin{abstract}
Two species of Witenia and a new pappocricetodontine genus and species from the late Eocene and early Oligocene of south-east Serbia are described. The Pappocricetodontinae a subfamily originally based on the small Pappocricetodon rencunensis from China has become a polyphyletic entity due to inclusion of the genus Witenia. The dental morphology of the late Eocene Witenia europea nov. sp. is very similar to that of the middle Eocene Pappocricetodon antiquus, but its molar enamel is more primitive. The small Bustrania dissimile nov. gen. nov. sp., the dominant species in the late Eocene locality of Buštranje, is defined and allocated to the Pappocricetodontinae.
\end{abstract}

Keywords Eocene $\cdot$ Oligocene $\cdot$ Rodentia $\cdot$ Muridae $\cdot$ South-east Serbia

\section{Introduction}

The isolated teeth of Pappocricetodontinae that will be described below were collected from the Eocene locality Buštranje in the Pčinja basin and the early Oligocene sites of Strelac-1, Strelac-3 and Valniš in the Koritnica-Babušnica ba$\sin$. The location and geological setting of these localities and

This is the fifth paper in the series "The Paleogene rodent faunas from south-east Serbia".

This article is registered in Zoobank under:

urn:lsid:zoobank.org:pub:D66CA1BA-F835-4B6D-9C1C-F2E67527577B

Electronic supplementary material The online version of this article (https://doi.org/10.1007/s12549-018-0343-2) contains supplementary material, which is available to authorized users.

Hans de Bruijn

hdbruijn@uu.nl

Zoran Marković

zoran.markovic@nhmbeo.rs

Wilma Wessels

w.wessels@uu.nl

Andrew A. van de Weerd

a.vandeweerd@uu.nl

1 Department of Earth Sciences, Utrecht University, Princetonlaan 8A, 3584 CB Utrecht, The Netherlands

2 Natural History Museum, Njegoševa 51, Belgrade, Serbia an overview of the rodent assemblages have been described in de Bruijn et al. (2018). Three groups of rodents have been studied so far, the Diatomyidae (Marković et al. (2018), the Melissiodontinae (Wessels et al. (2018)) and the Paracricetodontinae (van de Weerd et al. (2018). Studies of the Dipodidae and the Pseudocricetodontidae from these faunas are in progress. The composition of the rodent faunas of the localities is shown in Table 1. This table shows the current identifications and numbers which may differ in details from earlier publications in the series "The Paleogene rodent faunas from south-east Serbia”.

\section{Material and methods}

The terminology of parts of the cheek teeth follows Freudenthal et al. (1994) and is shown in Fig. 1. The family name Muridae is used as the equivalent of the superfamily Muroidea. The assemblages of isolated teeth were obtained by wet-screening fossiliferous matrix on a set of stable sieves (finest mesh $0.5 \mathrm{~mm}$ ). For methods, see de Bruijn et al. (2018). The measurements of the teeth have been taken with a Leitz ortholux measuring microscope with mechanical stage and measuring clocks. The pictures were made using a table-top and a high-resolution SEM. All specimens are figured as from the left side; is the original from the right side, this is indicated by underlining its number on the figure. Lowercase letters refer to the lower dentition, upper case letters refer to the upper dentition. 
Table 1 Distribution of rodent species in the faunas of south-east Serbia based on the total numbers of first and second molars

\begin{tabular}{|c|c|c|c|c|c|c|c|c|c|c|}
\hline \multirow[t]{2}{*}{ Family } & \multirow[t]{2}{*}{ Subfamily } & \multirow[t]{2}{*}{ Genus and species } & \multicolumn{2}{|l|}{ Eocene } & \multicolumn{6}{|c|}{ Early Oligocene } \\
\hline & & & Zvonce & Buštranje & Strelac-1 & Strelac-2 & Strelac-3 & Valniš & Raljin & $\begin{array}{l}\text { Total } \\
\text { M1- M2 }\end{array}$ \\
\hline Diatomyidae & Diatomyinae & Inopinatia balkanica & & & 7 & 4 & 3 & 49 & 2 & 65 \\
\hline Dipodidae & primordial Zapodidae & Heosminthus borrae & & & & $\mathrm{X}$ & 22 & 20 & 1 & 43 \\
\hline \multirow[t]{15}{*}{ Muridae } & Pseudocricetodontinae & $\begin{array}{l}\text { Heterocricetodon } \\
\text { nov. sp. A }\end{array}$ & & & 14 & 5 & 6 & 49 & 4 & 78 \\
\hline & & $\begin{array}{l}\text { Pseudocricetodon } \\
\text { nov. sp. (small) }\end{array}$ & & 29 & & & 14 & & & 43 \\
\hline & & $\begin{array}{l}\text { Pseudocricetodon } \\
\text { montalbanensis }\end{array}$ & & & 4 & & 23 & 28 & 8 & 63 \\
\hline & Paracricetodontinae & Paracricetodon dehmi & & & 3 & & $\mathrm{X}$ & 10 & & 13 \\
\hline & & Paracricetodon gracilis & & & & & 2 & 11 & $?$ & 13 \\
\hline & & Paracricetodon stojanovici & & 75 & 45 & 26 & 30 & 127 & 9 & 312 \\
\hline & Pappocricetodontinae & Witenia cf. fusca & & & 5 & & $\mathrm{X}$ & 2 & & 7 \\
\hline & & Witenia europea nov.sp. & & 21 & & & & & & 21 \\
\hline & & $\begin{array}{l}\text { Bustrania dissimile } \\
\text { nov. gen. nov. sp. }\end{array}$ & & 601 & & & & & & 601 \\
\hline & Melissiodontinae & cf. Edirnella sp. 2 & & & 6 & 1 & & & & 7 \\
\hline & & Mogilia lautus & & & $\mathrm{X}$ & & & 34 & 1 & 35 \\
\hline & & Mogilia miloshi & 28 & 30 & & & & & & 58 \\
\hline & & cf. Edirnella sp. 1 & & 4 & & 1 & & & & 5 \\
\hline & & cf. Edirnella sp. indet. & $\mathrm{X}$ & & & & & & & 1 \\
\hline & ?Spalacinae & nov. gen.1 sp. A & 3 & & & & & & & 3 \\
\hline \multicolumn{3}{|c|}{ Total number of upper and lower M1 and M2 in each locality } & 31 & 760 & 84 & 37 & 100 & 330 & 25 & 1368 \\
\hline
\end{tabular}

Sections have been made of incisors and molars in order to study the microstructure of the enamel. Methods of making preparations of incisors and molars have been described by Kalthoff $(2000,2006)$ Koenigswald (2004) and Bergqvist and von Koenigswald (2017). Over the years, a practical method of making the preparations has been developed by one of us $(\mathrm{HdB})$, a description of which can be downloaded as electronic supplementary material with this paper.

Abbreviations and terminology used in the description of the microstructure of enamel are: enamel dentine junction (EDJ), Hunter Schreger band (HSB), inclination = angle between the HSB and the normal to the EDJ, portio interna $(\mathrm{PI})$, portio externa $(\mathrm{PE})$, outer enamel surface $(\mathrm{OES})$, external enamel layer without prims (PLEX), inter prismatic matrix (IPM), basal ring of lamellar enamel in the cheek teeth (BRLE), and radial enamel = enamel with parallel prisms that are at right angles to the EDJ.

Abbreviations for measurements and descriptions are: Number of specimens $(\mathrm{N})$, range of measurements (R), length (L), width (W), sinistral (sin) and dextral (dex).

The inventory numbers of the teeth that will be discussed are for Buštranje (031): BUS 601-660, BUS 781-1300 and BUS 1451-1480, for Valniš (027): VA 1021-1030 and for Strelac-1 (024): STR1 291-300. The material described below will be housed in the Natural History Museum of Belgrade. A representative set of casts is kept in the department of Earth Sciences of Utrecht University.

\section{Taxonomy}

Rodentia Bowdich, 1821

Muridae Illiger, 1811

Pappocricetodontinae Tong, 1997

Pappocricetodon Tong, 1992 (Type genus)

Genera included: Palasiomys Tong, 1997; Raricricetodon Tong, 1997; Ulaancricetodon Daxner-Höck, 2000; Witenia de Bruijn et al., 2003 and Bustrania nov. gen.

Introduction

The type species of the genus Pappocricetodon is the small primitive cricetid Pappocricetodon rencunensis Tong, 1992 from the later part of the middle Eocene in the Hedi Formation of the Yuanqu basin (Henan province, China). Tong (1997) diagnosed the Pappocricetodontinae on the basis of dental morphology. The Eocene cricetids sharing the primitive dental characteristics used by Tong (1997) to define the subfamily are all small, from Eocene localities in China and may well represent the same clade. However, de Bruijn et al. (2003) described two large cricetids, species of Witenia, from the late Eocene of Süngülü (Lesser Caucasus, Turkey) and allocated these to the Pappocricetodontinae on the basis of dental morphology. Gomes Rodrigues et al. (2012) followed de Bruijn et al. (2003) by assigning a new large lophodont Witenia yolua from the early part of the late Oligocene of 


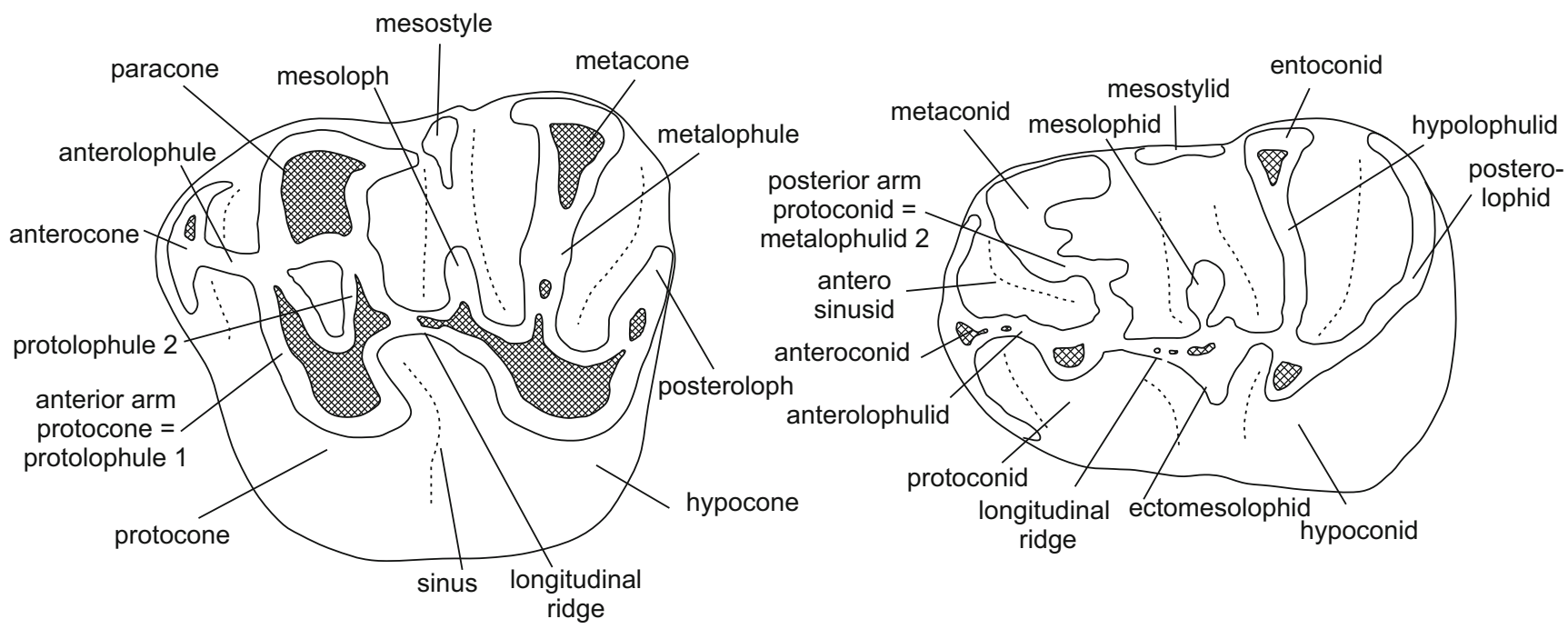

Fig. 1 Terminology of elements of the molars of the Pappocricetodontinae used in the descriptions

Ulantatal (China) to the Pappocricetodontinae. Unfortunately, the early history of the Muridae is not known well enough to recognise supra-generic clades among the Eocene representatives. Including the large lophodont Witenia species, the small bunodont species Pappocricetodon rencunensis and Palasiomys conulus and the small lophodont Raricricetodon zongtiaensis and Ulaancricetodon badamae into one subfamily, on the basis of shared primitive dental characteristics, implies that this group is probably polyphyletic. This conclusion is supported by differences in enamel microstructure (see below). The three Serbian species that will be described below illustrate this dilemma, so our allocation of the Serbian species to the Pappocricetodontinae is tentative.

Witenia de Bruijn et al., 2003

Type species: Witenia flava de Bruijn et al., 2003 from Süngülü (Turkey).

Other species included: Witenia fusca de Bruijn 2003, Witenia yolua Gomes Rodrigues et al. 2012, Witenia europea nov. sp.

Witenia europea nov. sp. (Figs. 2g-1, 3f-k, 4d-f, 5c).

Derivatio nominis: europea, because this is the first record of this genus from Europe.

Type locality: Buštranje (Serbia).

Type level: (? late) Eocene.

Holotype: M1 dext BUS-608. Fig. 2j.

Material and measurements: Table 2 and Fig. $2 \mathrm{~g}-1$.

Diagnosis: Witenia europea is a large Witenia species. The $\mathrm{m} 3$ is on average slightly longer than the $\mathrm{m} 1$. The anterocone(id) of the M1 (m1) is small or absent. The anterior arm of the protocone of the M1 is strong, directed antero-labially and in some M1 connected to the paracone (protolophule 1). The anterolophule is a weak, low cingulum. The slightly backward directed protolophule 2 of the M1 inserts either just behind the protocone on the longitudinal ridge or on the protocone. The strong anterior arm of the protocone of the M2 forms a protolophule 1; the protolophule 2 is weaker. The slightly forwards directed metalophule of the M2 inserts on the anterior side of the hypocone. The sinus of the upper molars is directed forward.

Differential diagnosis: The M1 of Witenia europea, relative to the M2, shorter than in W. flava, W. fusca and W. yolua. The anterocone complex of the M1 is much less developed in $W$. europea than in the other species of the genus and structurally similar to that of Pappocricetodon antiquus Wang and Dawson, 1994 from the middle Eocene of Janggsu Province, China.

Description of the type material

M1: The anterocone is either very small or absent. If present, it is situated labially at the end of the very strong anterior arm of the protocone. In $2 / 3$ of the M1, the anterior arm of the protocone is connected to the paracone and thus named protolophule 1 . The transverse protolophule 2 inserts just behind the protocone on the longitudinal ridge. The anteroloph is weak and low. The metalophule inserts on the anterior side of the hypocone. The mesoloph is of medium length and in some specimens there is a small mesostyle. The sinus is directed forward. The M1 has three roots.

M2: The M2 is as large as the M1. The anterolophule of the M2 is much stronger than in the M1. The strong protolophule 1 is formed by the anterior arm of the protocone; the protolophule 2 is weaker. The mesoloph is of medium length and the sinus is directed forward. In contrast to the M1, a small mesostyle is absent but the paracone of the M2 has a posterior 
spur. The transverse metalophule inserts on the anterior side of the hypocone. The M2 has three roots.

M3: The two M3 show a rather different morphology. One shows all the elements of the M2 including an incomplete protolophule 2 and a long mesoloph (Fig. 21), the other is so much reduced that the metalophule has become short and irregular and the sinus very shallow (Fig. 2i). The roots of the $\mathrm{M} 3$ are not preserved.

m1: The anteroconid is small or just a low cingulum, which is connected to the protoconid by a short anterolophulid. The metalophulid 1 is absent, but the metalophulid 2 (= posterior arm of the protoconid) is complete. The metaconid is higher a
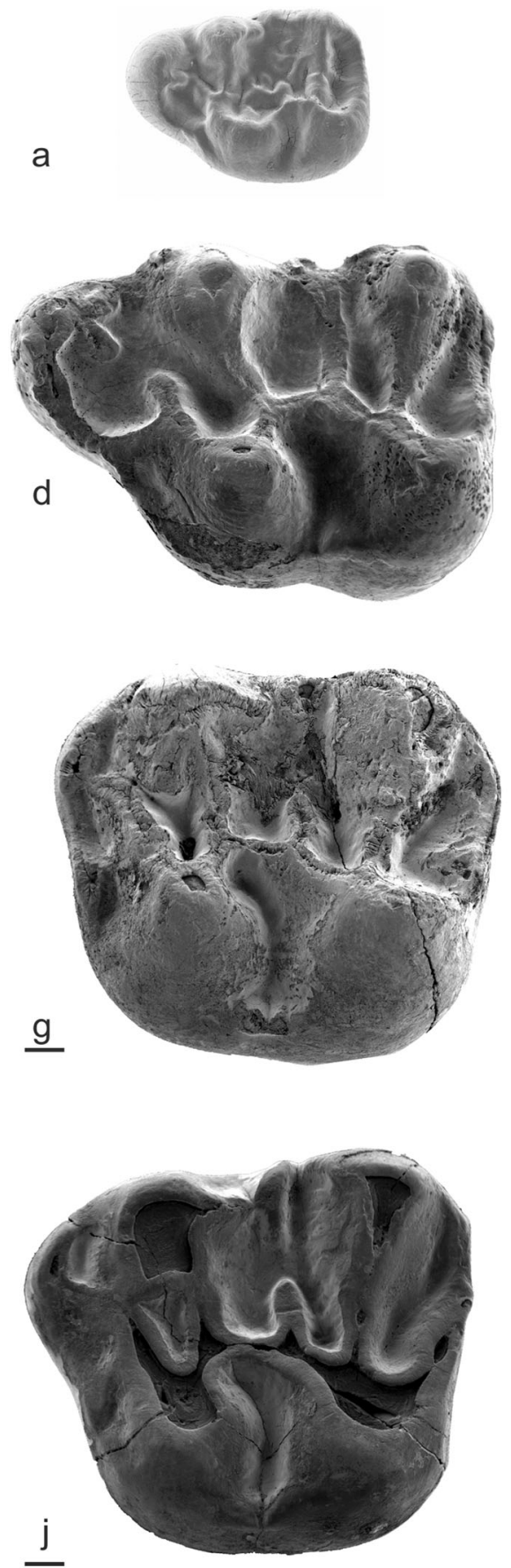

b

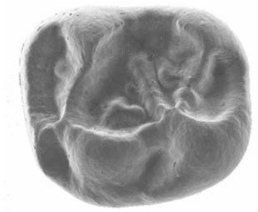

$\underline{e}$

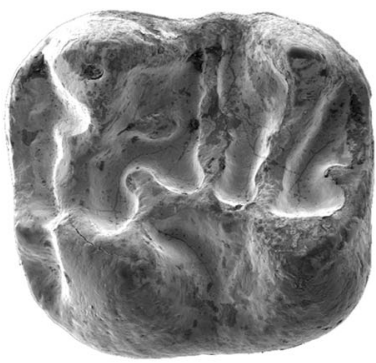

$\underline{\mathrm{h}}$
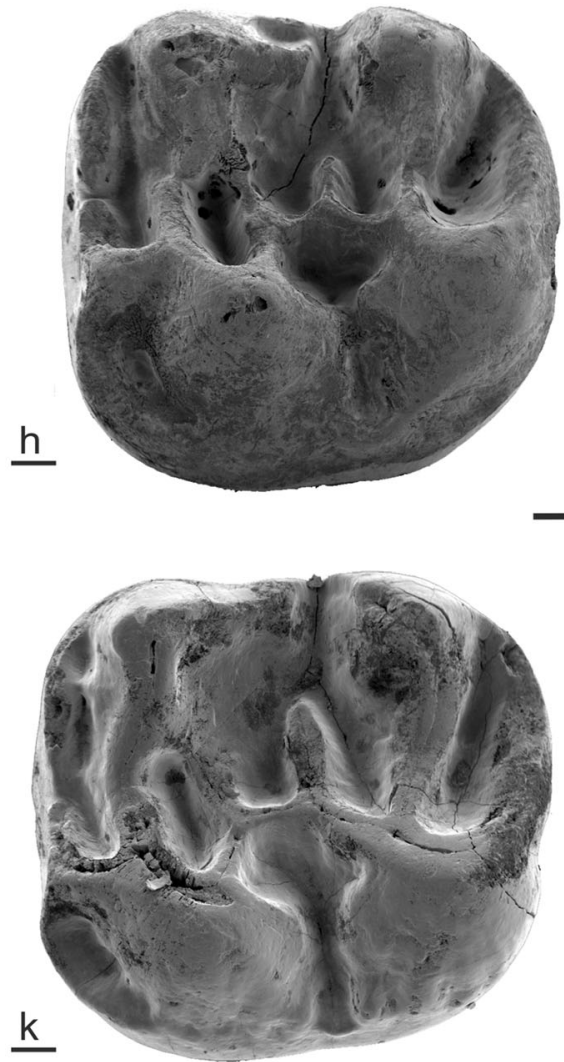

f

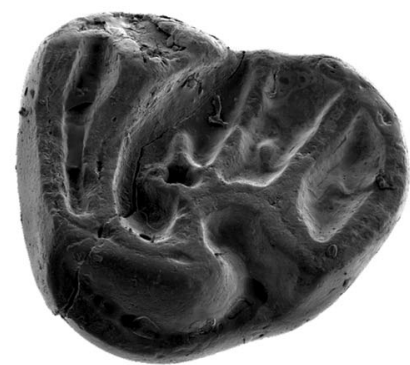

i

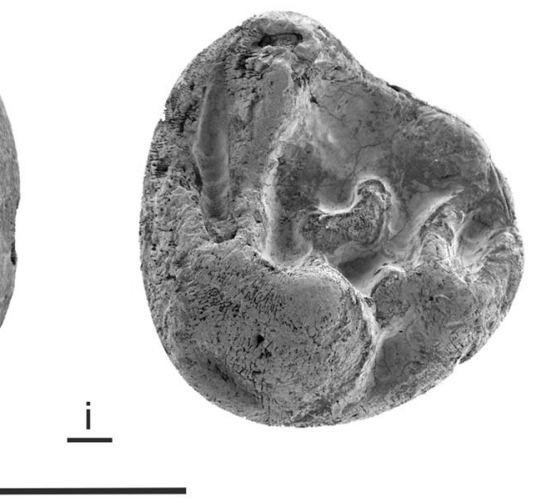

C

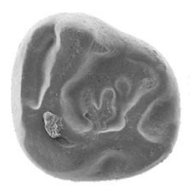

$1 \mathrm{~mm}$

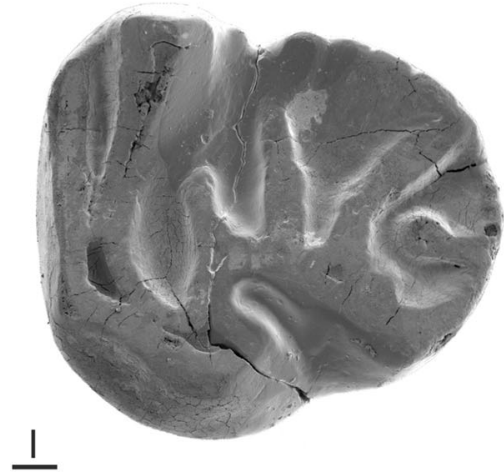

Fig. 2 Bustrania dissimile nov. gen. nov. sp. from Buštranje (031, type locality). a M1 (BUS-782). b M2 (BUS-893). c M3 (BUS-973). Witenia cf. fusca from Valniš (027) and Strelac-1 (024) d M1 (VA-1021). e M2 (VA-293). f M3 (STR1-295). Witenia europea nov. sp. from Buštranje
(031) g M1 (BUS-607). h M2 (BUS-619). i M3 (BUS-627). j M1 (BUS608 holotype), k M2 (BUS-616). 1 M3 (BUS-626). Bustrania has been added to this figure to illustrate the size difference between Bustrania and Witenia 
a

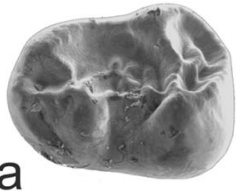

b

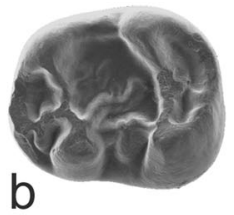

C
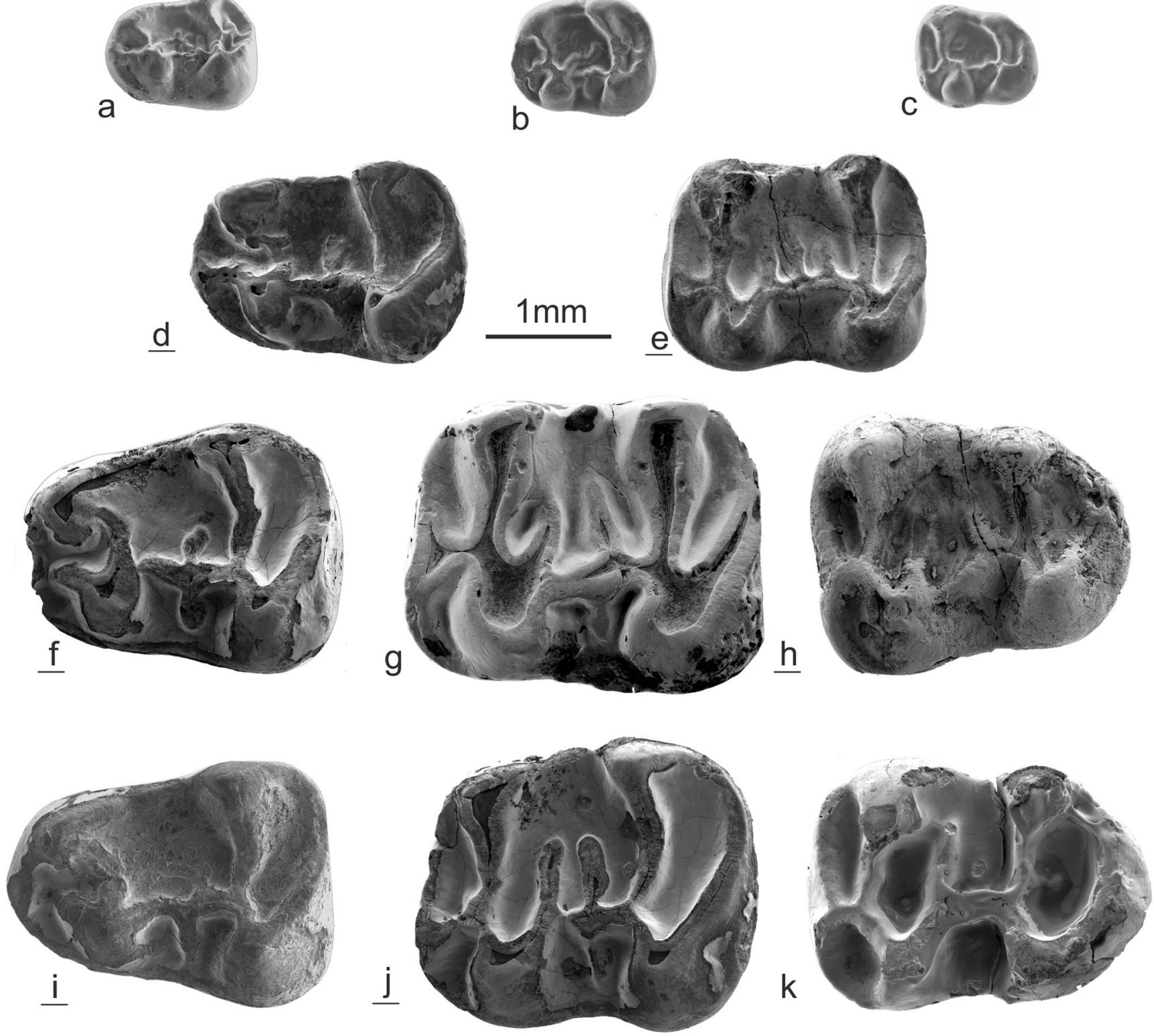

Fig. 3 Bustrania dissimile nov. gen. nov. sp. from Buštranje (031). a m1 (BUS-1103). b m2 (BUS-1197). c m3 (BUS-1273). Witenia $\mathrm{cf}$. fusca from Strelac-1 (024). d m1 (STR1-297). e m2 (STR1-258). Witenia europea nov. sp. from Buštranje (031). f m1 (BUS-639). g m2 (BUS-

641). h m3 (BUS-658). i m1 (BUS-636). j m2 (BUS-646). $\mathbf{k} \mathrm{m} 3$ (BUS651). Bustrania has been added to this figure to illustrate the size difference between Bustrania and Witenia

than the protoconid. The more or less straight longitudinal ridge bears an ectomesolophid and a short, weak mesolophid. The transverse hypolophulid inserts on the anterior arm of the hypoconid. The long posterolophid descends from the hypoconid and ascends to the tip of the entoconid. The $\mathrm{m} 1$ has two roots.

m2: The anterolophid is divided into a long straight lingual part and a short labial part by a short anterolophulid. Some specimens have a small anteroconid where the anterolophulid and anterolophid meet. The transverse metalophulid 1 inserts on the anterior part of the protoconid and the long posterior arm of the protoconid ends free in the central basin. The parallel mesolophid and posterior arm of the protoconid have about the same length. The slightly forward directed hypolophulid inserts on the anterior arm of the hypoconid. The long posterolophid descends from the hypoconid and ascends to the tip of the entoconid. The $\mathrm{m} 2$ has two roots.

m3: The dental pattern of the $\mathrm{m} 3$ is very similar to that of the $\mathrm{m} 2$; the posterior part of the $\mathrm{m} 3$ is slightly reduced. In $1 / 3$ of the $\mathrm{m} 3$ the mesolophid is absent. The $\mathrm{m} 3$ has two roots. 
Fig. 4 Bustrania dissimile nov.gen. nov. sp. (Buštranje type locality). a sagital section of lower incisor. b enlargement of a. c enlargement of $\mathrm{b}$. Witenia europea nov. sp. (Buštranje, type locality). d sagital section of lower incisor. e enlargement of $\mathrm{d}$. f enlargement of $\mathrm{e}$
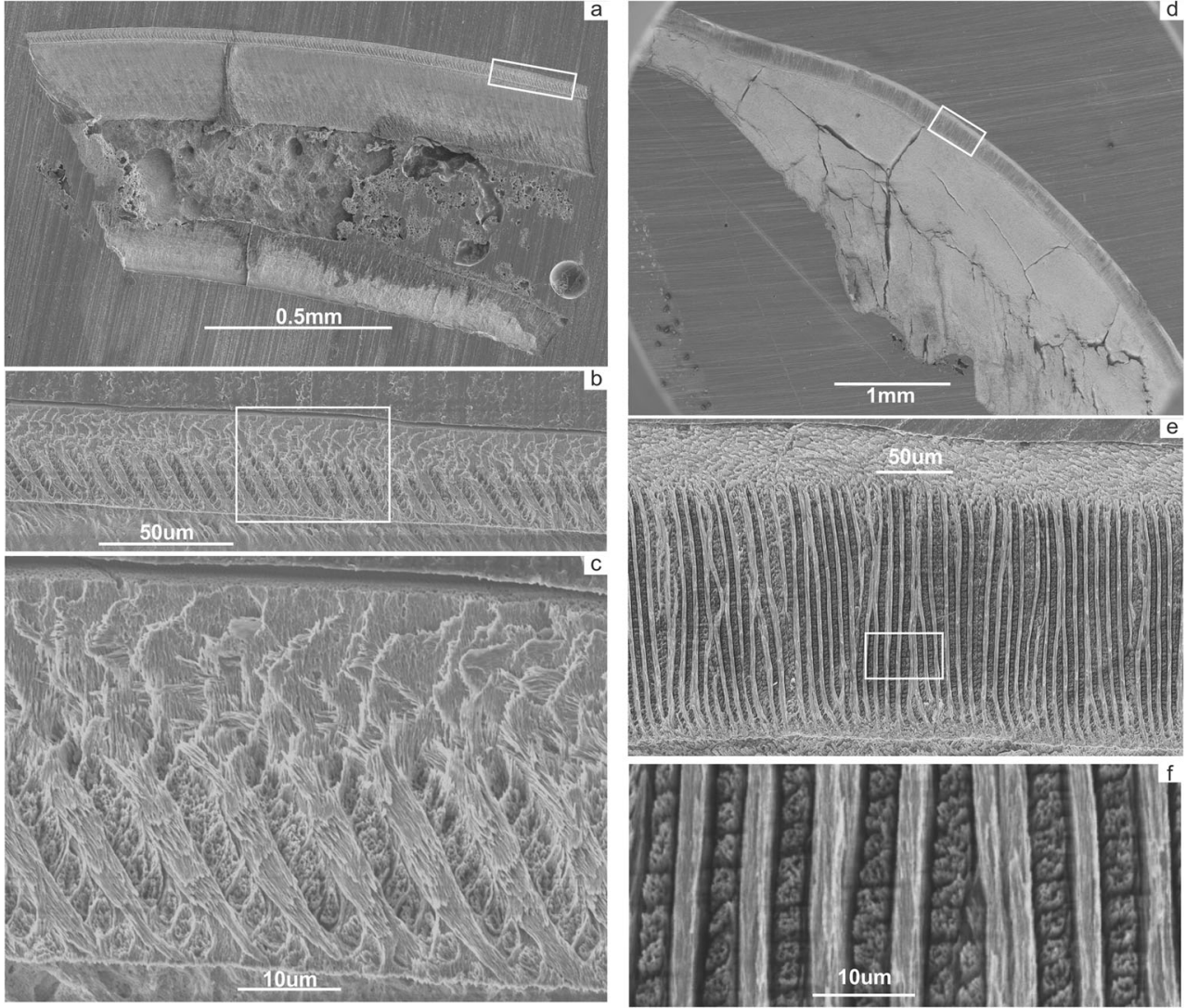

The microstructure of the enamel of the lower incisor (Fig. 4d-f)

The outer enamel surface is rugose (similar to that of spalacids) and shows a very shallow sulcus. The PI of the rather thick enamel $(200 \sim \mu \mathrm{m})$ is $\sim 80 \%$ of the total. The PI consists of uniserial, not inclined, transverse HSB with IPM parallel to the prisms. The relatively thin PE consists of tangential enamel and the PLEX is absent.

The microstructure of the enamel of the molars (Fig. 5a-c)

The basal ring of lamellar enamel (BRLE), a common feature in most Muridae molars, is absent. Some extremely weak prism decussation is present in a small portion of the lateral side of the molar fragment of Witenia europea. A similar structure has been observed in the Muridae subfamilies Eumyinae, Spalacinae and Rhizomyinae by Koenigswald (2004) and described as transitional between his P-type (no BRLE) and Ctype (well-developed BRLE). Since the supposedly derived Ctype is already fully developed in Pappocricetodon antiquus from the middle Eocene of Mongolia (Koenigswald 2004) and reduction of this feature through time is unlikely, this difference in enamel microstructure among Pappocricetodontinae supports our earlier suggestion that this subfamily contains an array of genera of different lineages and thus is polyphyletic.
Witenia cf. fusca Bruijn et al., 2003

(Figs. 2d-f and 3d-e)

Type locality: Süngülü (Turkey).

Age: late Eocene

Material and measurements: 2 specimens from Valniš (027), 5 specimens from Strelac-1 and 1 from Strelac-3 (026). The $\mathrm{m} 3$ is not known. Table 3, Figs. $2 \mathrm{~d}-\mathrm{f}, 6$, and 7.

Description of the specimens

M1: The low, but prominent, anterocone has a labial position and is connected to the paracone and protocone by low ridges along the margins of the occlusal surface. The anterior arm of the protocone is interrupted and reaches neither the anterocone nor the paracone. The protolophule 2 is directed posteriorly and inserts on the longitudinal ridge well behind the protocone. The low mesoloph is long and reaches the buccal margin between the paracone and the metacone. The transverse metalophule inserts on the anterior part of the hypocone. The narrow, straight posteroloph reaches the base of the metacone. The sinus is directed forward. The M1 has three roots.

M2: The outline of the M2 is square, the hypocone seems in a slightly more buccal position when compared with other 
Fig. 5 Witenia europea nov. sp. from Buštranje (type locality). a Transverse section of the $\mathrm{m} 2$. b detail of a. $\mathbf{c}$ detail of $b$
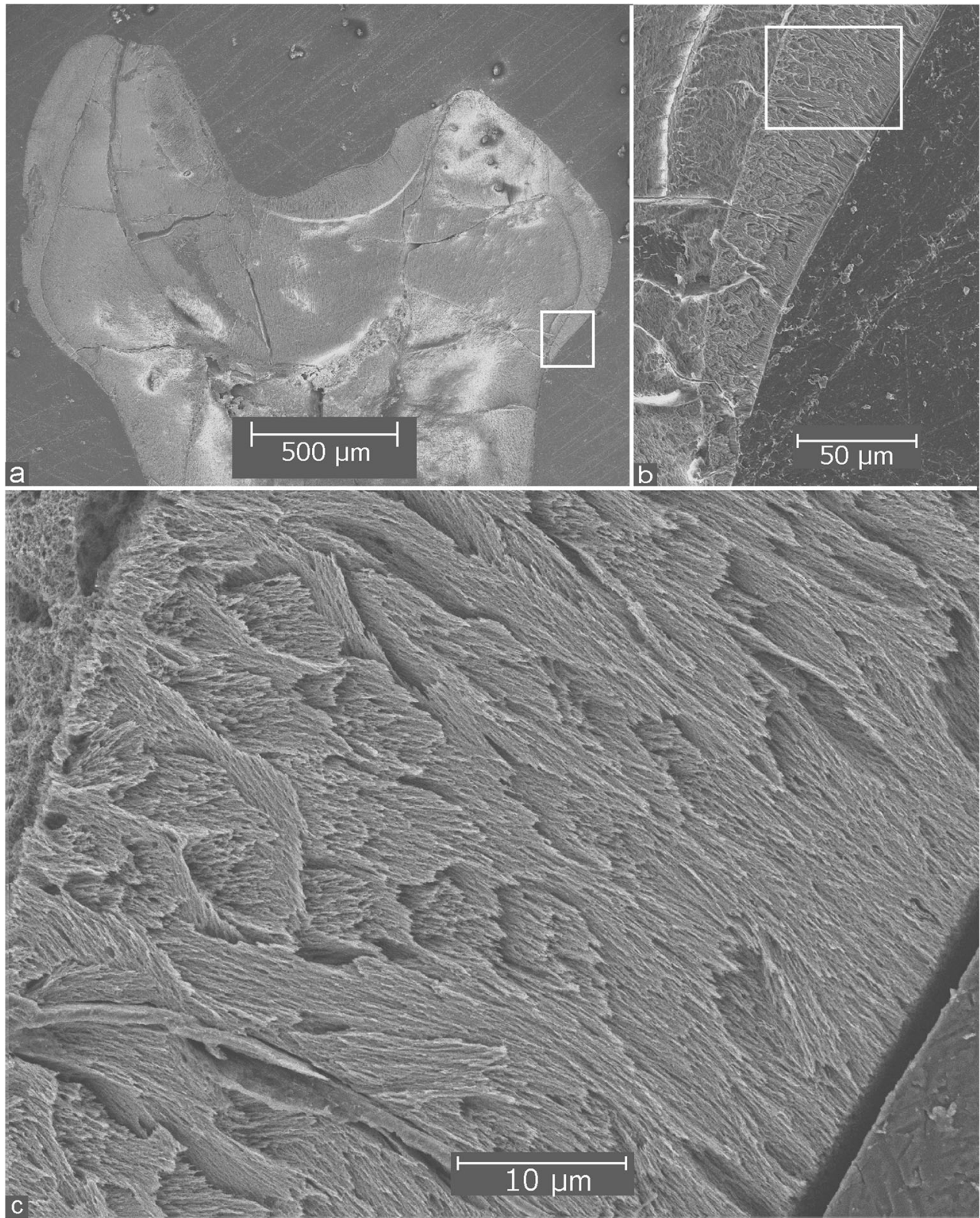

Table 3 Measurements of the cheek teeth of Witenia $\mathrm{cf}$. fusca from Strelac-1, Strelac-3 and Valniš

\begin{tabular}{|c|c|c|c|c|c|c|}
\hline \multirow[t]{2}{*}{ Strelac-1 } & \multicolumn{3}{|c|}{ Length (mm) } & \multicolumn{3}{|c|}{ Width (mm) } \\
\hline & Range & Mean & $\mathrm{N}$ & Mean & Range & $\mathrm{N}$ \\
\hline M2 & $1.93-2.09$ & 2.01 & 2 & 1.86 & $1.83-1.88$ & 2 \\
\hline M3 & - & 2.00 & 1 & 1.78 & - & 1 \\
\hline $\mathrm{m} 1$ & - & 2.26 & 1 & 1.57 & - & 1 \\
\hline $\mathrm{m} 2$ & $1.94-2.27$ & 2.11 & 2 & 1.73 & $1.68-1.78$ & 2 \\
\hline \multicolumn{7}{|l|}{ Strelac-3 } \\
\hline M3 & - & - & - & 2.00 & - & 1 \\
\hline \multicolumn{7}{|l|}{ Valniš } \\
\hline M1 & - & 2.88 & 1 & 2.12 & - & 1 \\
\hline M2 & - & 1.74 & 1 & 1.64 & - & 1 \\
\hline
\end{tabular}

Table 2 Measurements of the cheek teeth of Witenia europea nov. sp. from the type locality Buštranje

\begin{tabular}{llllllll}
\hline Buštranje & \multicolumn{2}{l}{ Length $(\mathrm{mm})$} & & & \multicolumn{2}{l}{ Width $(\mathrm{mm})$} \\
\cline { 2 - 3 } \cline { 7 - 8 } & range & mean & $\mathrm{N}$ & & mean & range & $\mathrm{N}$ \\
\hline M1 & $2.38-2.71$ & 2.55 & 5 & & 2.37 & $2.19-2.73$ & 4 \\
M2 & $2.45-2.83$ & 2.60 & 5 & 2.43 & $2.10-2.60$ & 5 \\
M3 & $2.02-2.31$ & 2.17 & 2 & 2.18 & $2.12-2.24$ & 2 \\
m1 & $2.24-2.66$ & 2.44 & 4 & 2.02 & $2.00-2.04$ & 3 \\
m2 & $2.50-2.99$ & 2.72 & 5 & 2.20 & $2.02-2.36$ & 5 \\
m3 & $2.58-2.74$ & 2.67 & 3 & 2.08 & $2.02-2.24$ & 5 \\
\hline
\end{tabular}




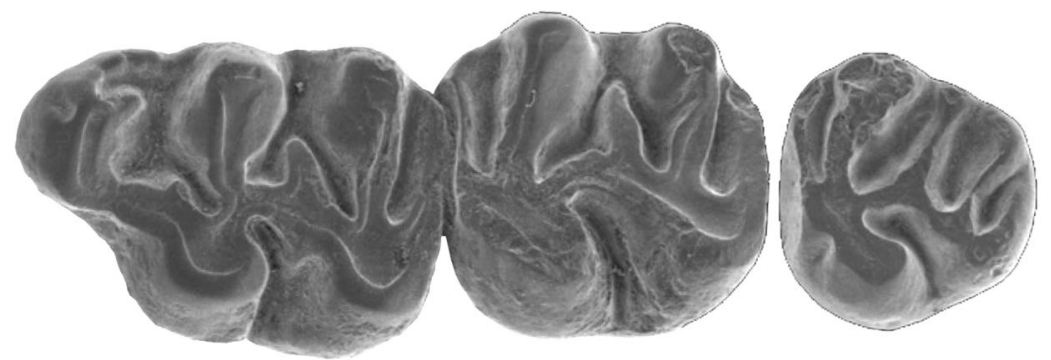

W. yolua Ulantatal-3 \& 4 (late Oligocene)
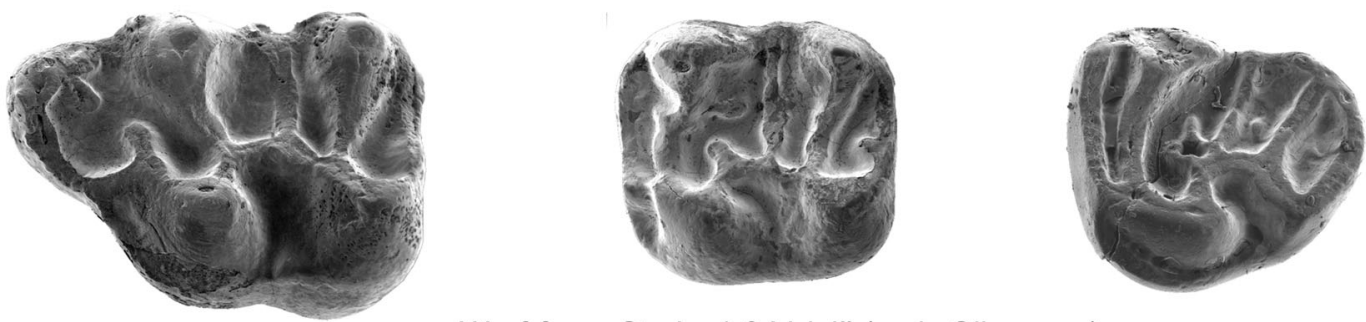

W. cf fusca Strelac1 \& Valniš (early Oligocene)
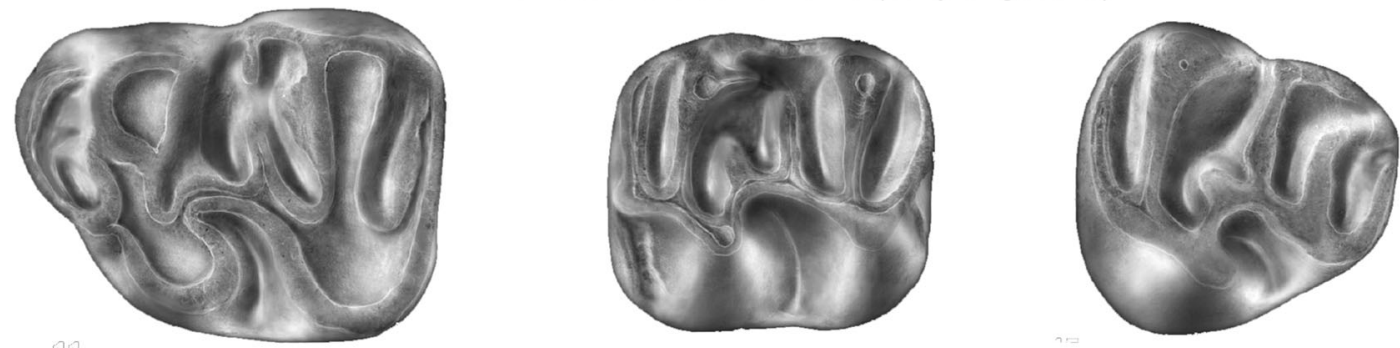

W. fusca Süngülü (? late Eocene)
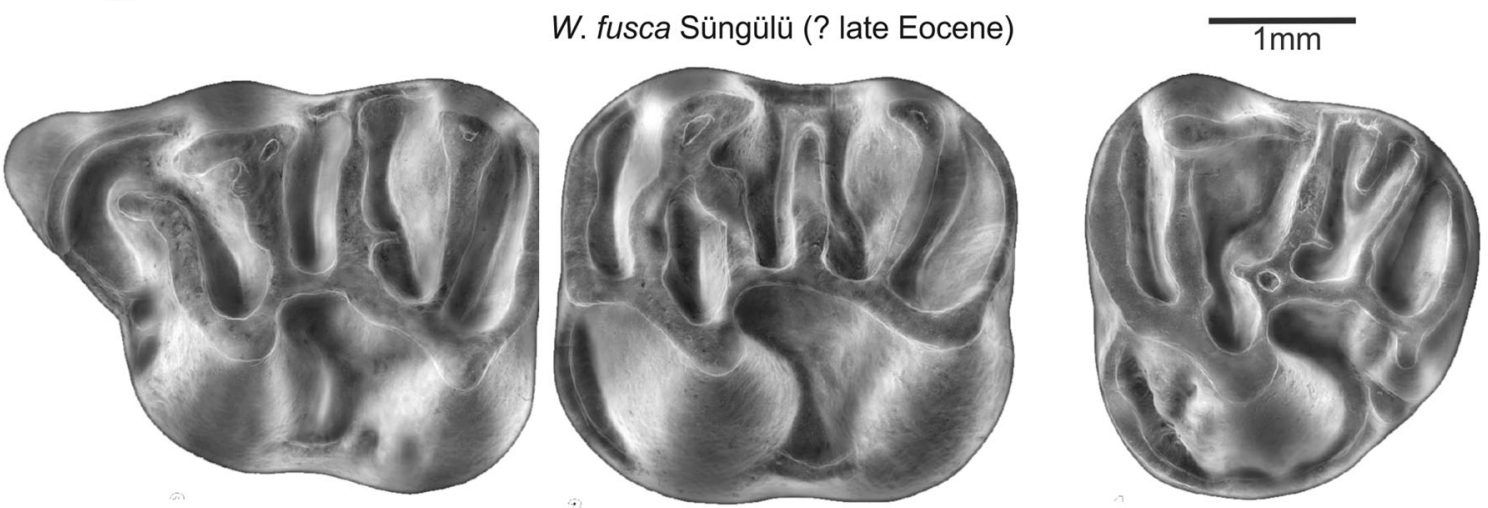

W. flava Süngülü (? late Eocene)
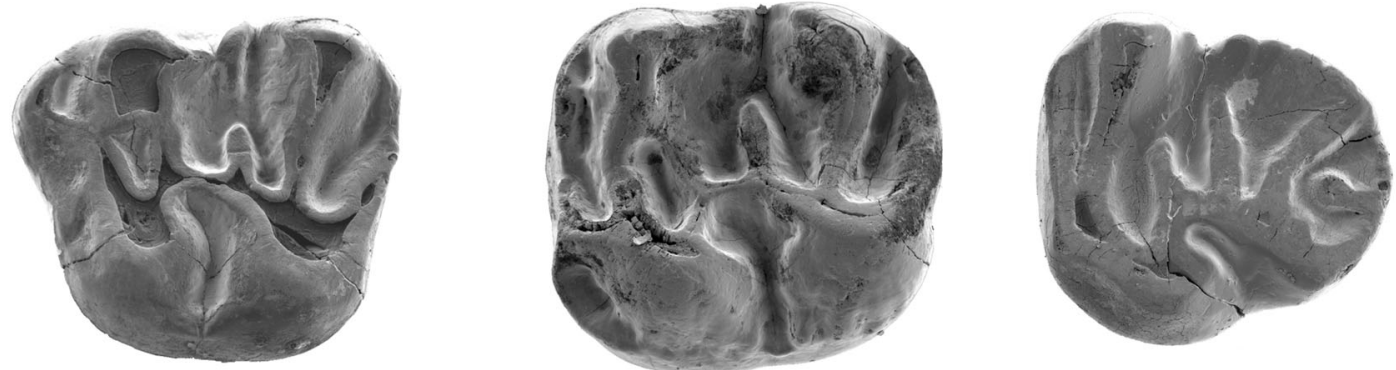

W. europea Buštranje (Eocene)

Fig. 6 Upper molars of all formally described Witenia species. W. yolua after Gomes Rodrigues et al. 2012. W. cf. fusca, W. fusca and W. europea after de Bruijn et al. (2003) 

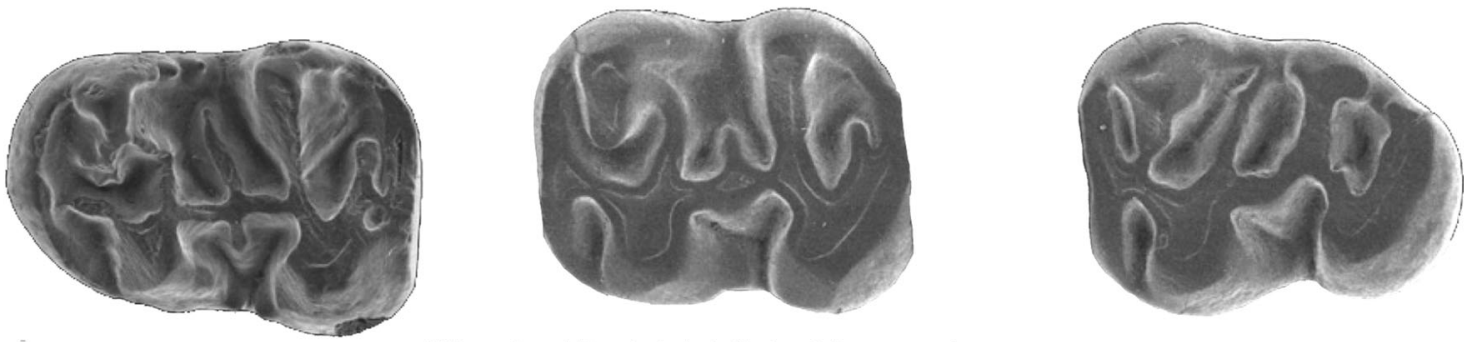

W. yolua Ulantatal-4 (late Oligocene)
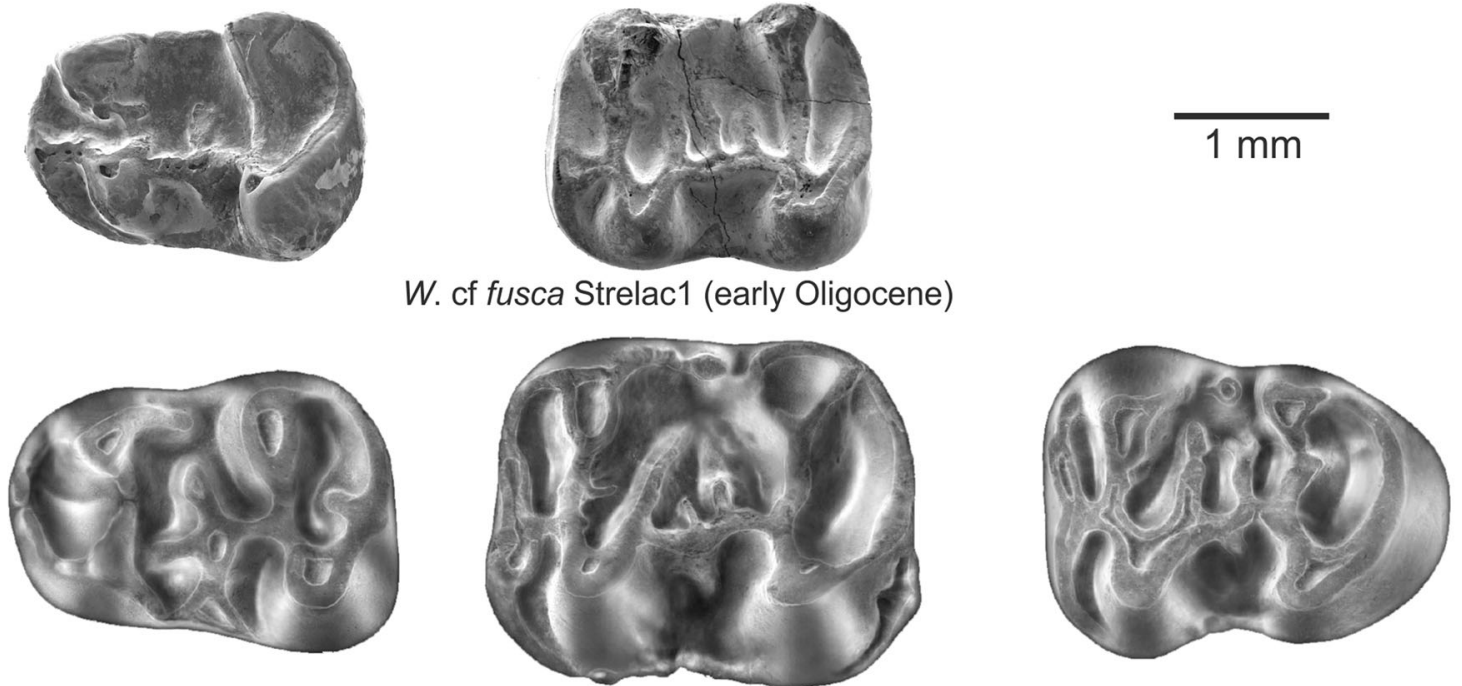

W. fusca Süngülü (? late Eocene)
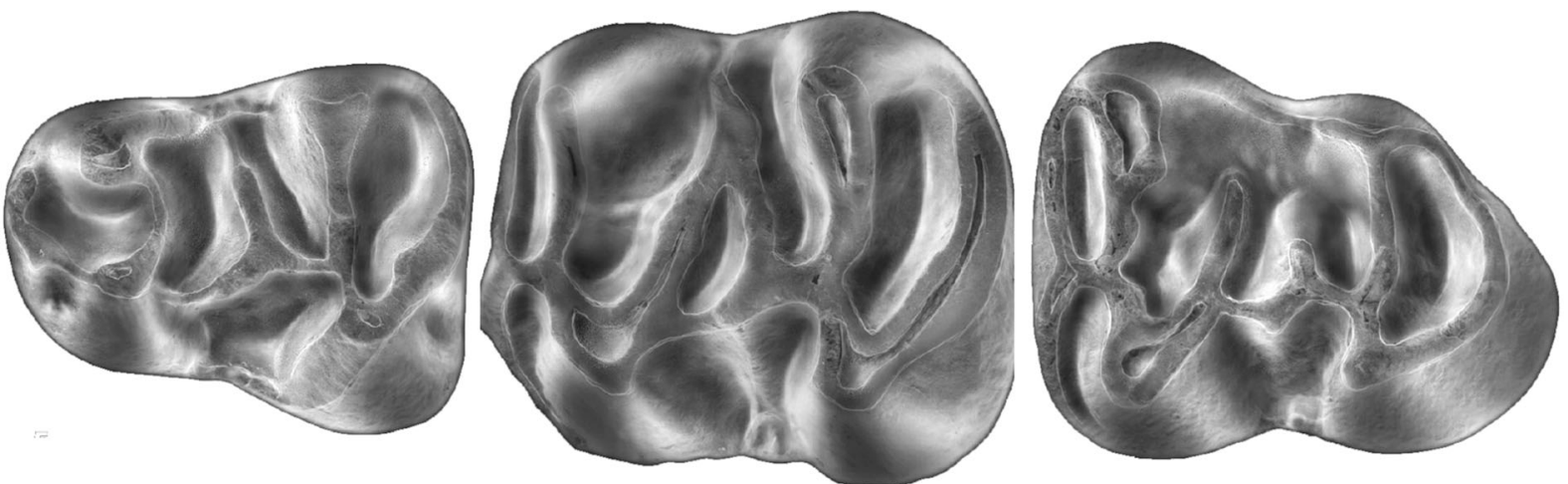

W. flava Süngülü (? late Eocene)
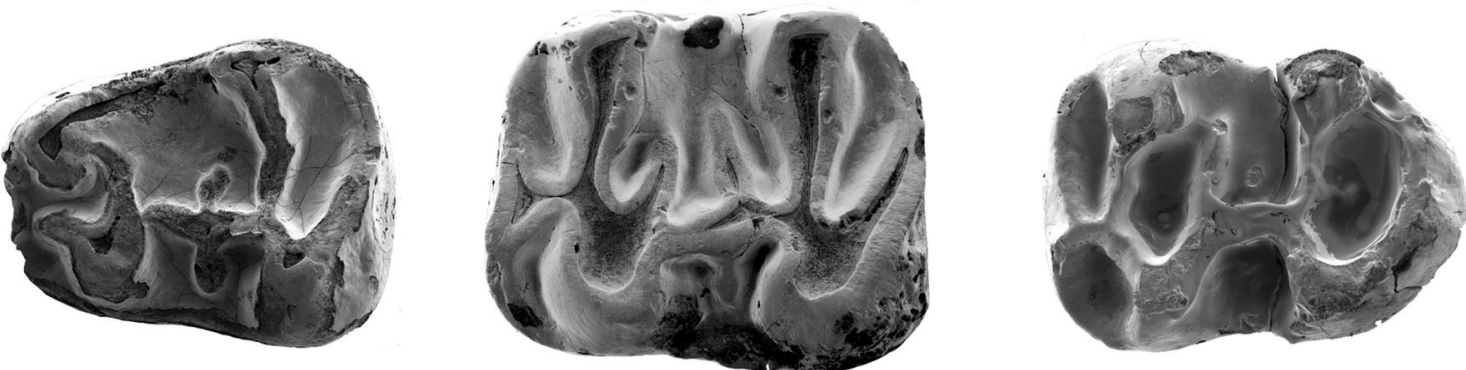

W. europea nov. sp. Buštranje (Eocene)

Fig. 7 Lower molars of all formally described Witenia species. W. yolua after Gomes Rodrigues et al. 2012. W. cf. fusca, W. fusca and W. europea after Bruijn et al. (2003) 
species (Fig. 6). The labial branch of the anteroloph is long, straight and rather narrow, but the lingual branch is short. The transverse protolophule- 1 inserts on the anterior side of the protocone. The protolophule- 2 is incomplete. The long, thin mesoloph reaches the labial border of the occlusal surface. The transverse metalophule inserts on the anterior side of the hypocone. The posteroloph is separated from the metacone by a narrow notch in one, but continues to the tip of the metacone in the other M2. The sinus is directed forward. The M2 has three roots.

M3: The long labial branch of the anteroloph reaches the tip of the paracone. A proper lingual branch is absent, but there is a low cingulum around the base of the protocone that reaches the hypocone. This configuration is strikingly similar to that in the M3 of Witenia flava from the type locality (Fig. 6). The transverse protolophule 1 inserts well in front of the protocone, which is situated somewhat posteriorly. The protolophule 2 is short and incomplete. The long mesoloph reaches the labial border of the occlusal surface. The metalophule is directed anteriorly and connects with the longitudinal ridge. The hypocone and the metacone are incorporated into the posteroloph. The sinus is directed forwardly. The M3 has three roots.

$\mathbf{m 1}$ : The tiny anteroconid is incorporated in a crescent-shaped ridge that is connected to the protoconid by a short anterolophulid. The metalophulid 1 is absent and the short metalophulid 2 inserts on the posterior side of the protoconid. A straight longitudinal ridge connects the protoconid to the hypoconid. The weak mesolophid is short. The transverse hypolophulid inserts on the anterior part of the hypoconid. The posterolophid descends from the hypoconid and ascends to the tip of the entoconid. The $\mathrm{m} 1$ has two roots.

m2: The dental pattern of the $\mathrm{m} 2$ resembles that of the Witenia flava $\mathrm{m} 2$ from the type locality (Fig. 7) in detail. The anterolophid has a long lingual and a short labial branch. The transverse metalophulid 1 inserts on the anterior part of the protoconid. The posterior arm of the protoconid does not reach the metaconid. There are two weak mesolophids. The transverse hypolophulid inserts on the anterior side of the hypoconid. The posterolophid connects the hypoconid and the tip of the entoconid. The $\mathrm{m} 2$ has two roots.

\section{Remarks}

The few teeth from Strelac-1, Strelac-3 and Valniš described above are morphologically very similar to those of Witenia fusca from the type locality, but are slightly smaller. Detailed comparison of these occurrences is impossible because the type material as well as the Serbian material is limited. Moreover, the two rather plump M1 from Süngülü (Turkey) are quite worn, while the single, more gracile, M1 available from Serbia is fresh. Because of these uncertainties we assign the Serbian specimens as Witenia cf. fusca.
Fig. 8 Bustrania dissimile nov. gen. nov. sp. from Buštranje (031) a M1 (BUS-782), b M1 (BUS-784), c M1 (BUS-817), d M1 (BUS-861), e f M1 (BUS-792), $\mathbf{g}$ M2 (BUS-893), h M2 (BUS-875), i M2 (BUS-871), j m2 (BUS-897), $\mathbf{k}-1$ M2 (BUS-918), $\mathbf{m}$ M3 (BUS-973), $\mathbf{n}$ M3 (BUS-977), o M3 (BUS), p M3 (BUS-1013), q-r M3 (BUS-1039)

The genus Witenia was first described from Süngülü, where it is present with two species, the large W. flava and the slightly smaller $W$. fusca. Both species are relatively rare, occurring with about 2 and $3 \%$ in the three rodent samples. Witenia europea nov. sp. is equally rare at about $3 \%$ in Buštranje. Witenia cf. fusca is rare too in Valniš and Strelac$3(<1 \%)$, but relatively well-represented in the Strelac-1 fauna with $6 \%$. Witenia yolua is known from several Chinese localities (Ulan 3, 4, 7 and 8, Ulantatal Formation, Inner Mongolia; Gomes Rodrigues et al. 2012). Comparison of these associations with the well-known sequence of the Valley of Lakes suggests a late Oligocene age (Gomes Rodrigues et al. 2014) for these samples. A single $\mathrm{m} 2$ present in the rich Valley of Lakes faunas of Mongolia has been assigned to Witenia sp. (López-Guerrero et al. 2017), dated latest early Oligocene (local biozone B). All the formerly named Witenia species are shown in Figs. 6 and 7 in order to facilitate comparison. Witenia europea with its poorly developed anterocone is the oldest and the most primitive species. The other three species show minor morphological differences in addition to the differences in size. However, the significance of these differences is difficult to judge considering the small number of specimens of these large rare cricetids.

Bustrania nov. gen.

Type species: Bustrania dissimile nov. sp. (Figs. 4, 8 and 9) Type locality: Buštranje (Serbia).

Type level: (? late) Eocene.

Derivatio nominis: This genus is named after the type locality of its type species.

Included species: Bustrania dissimile nov. sp.

Diagnosis: Since Bustrania is for the time being a monospecific genus the diagnosis of the genus is the same as for the type species.

Bustrania dissimile nov. sp.

Derivatio nominis: dissimile means inequality, which refers to the exceptionally variable pattern of the molars of this species.

Holotype: M1dext. BUS-792 (Fig. 8e, f).

Diagnosis: Bustrania dissimile is a small primitive cricetid with an exceptionally variable dental pattern in all cheek teeth (Figs. 8 and 9). The enamel of the relatively high-crowned molars extends to the roots (Fig. 11a). The anteroloph bears a cusp in some M1, but is merely a ridge in others. The 

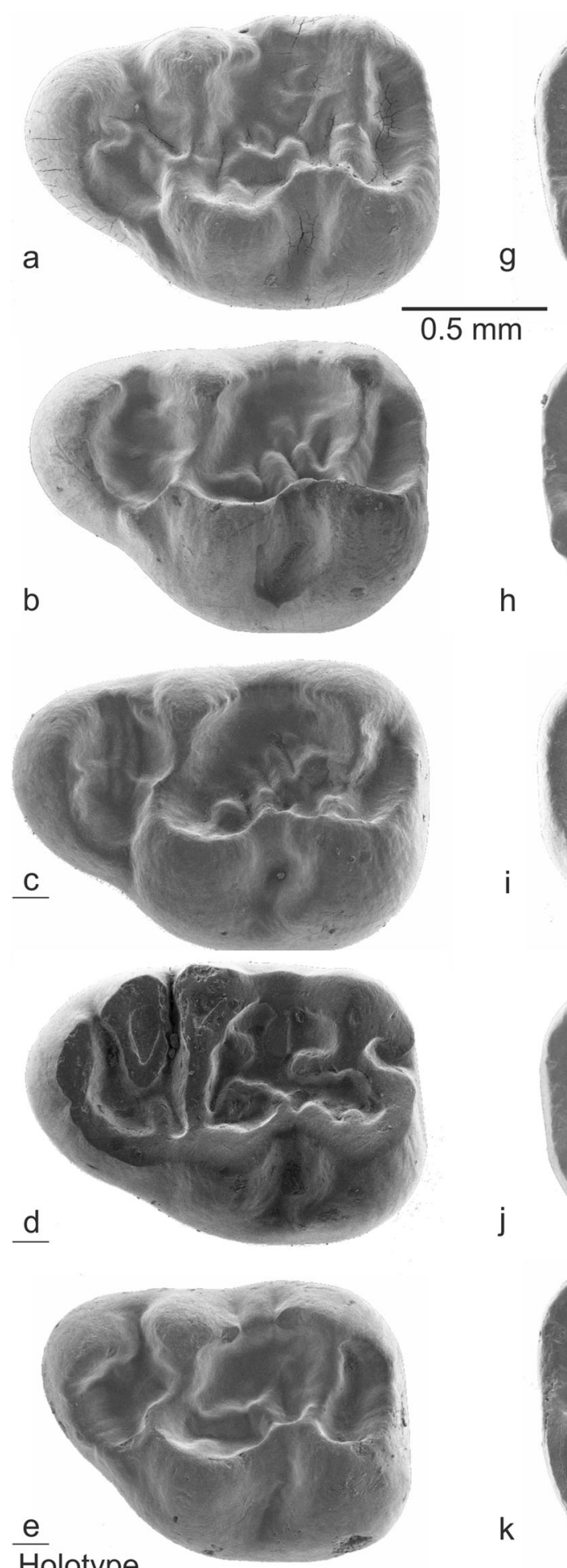

\section{Holotype}

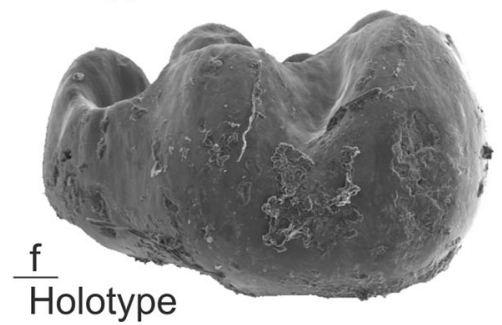

h

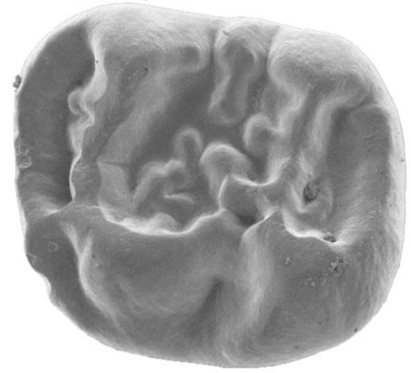

i
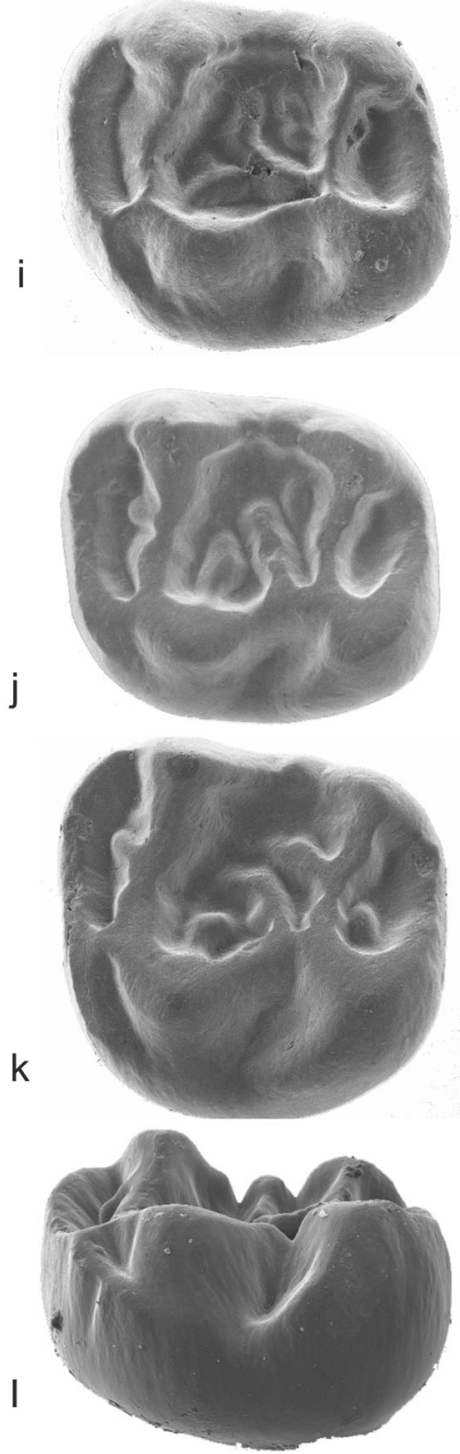

m

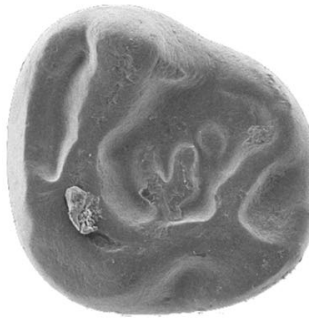

$0.5 \mathrm{~mm}$

n
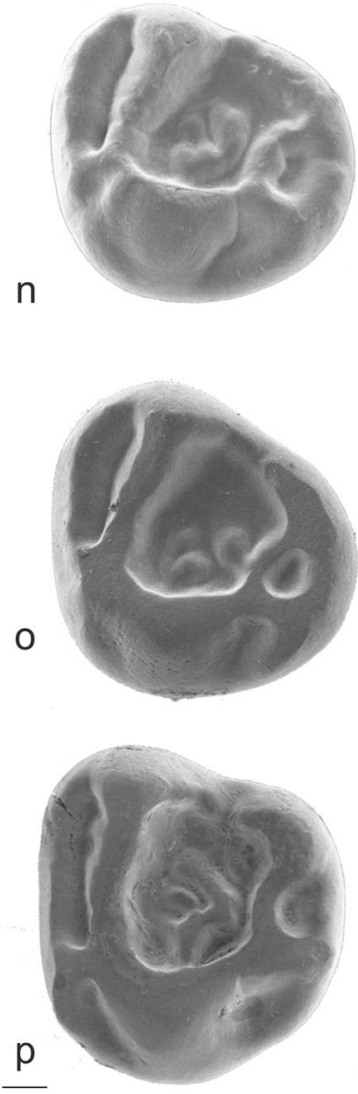

q
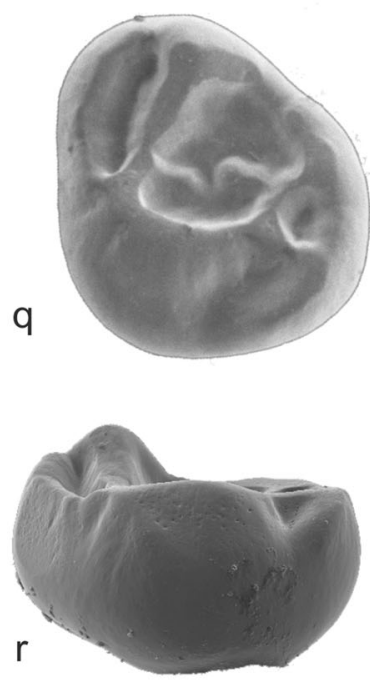
anterior arm of the protocone of the M1 may be strong (protolophule 1), but is usually weak and detached from the protocone and/or the anteroloph, and may be absent. Within the main basin of the majority of the upper and lower molars, there is an irregular array of low ridges and cuspules that can often not be homologized with the well-defined structural elements of the cricetid dental pattern. The sinus of the M1 and M2 is directed posteriorly as in paracricetodontines. The $\mathrm{m} 1$ and $m 2$ have on average about the same length, but the $m 3$ is shorter. The metaconid of the $\mathrm{m} 1$ is situated anteriorly of the protoconid and the anteroconid is small or absent. The posterior arm of the hypoconid is weak or absent in the $\mathrm{m} 1$; strong, weak, or absent in the $\mathrm{m} 2$ and absent in all $\mathrm{m} 3$.

Differential diagnosis: Bustrania dissimile differs from the various species of the genus Pappocricetodon Tong, 1992 by the complex unstable pattern within the main basins of the upper as well as of the lower cheek teeth. A somewhat similar dental pattern is present in the cheek teeth of the Eocene cricetid Zhungaromys gromovi Emry et al., 1998 from Kazakhstan, but the sinus of the upper cheek teeth of that species is very deep and forwardly directed, while those of Bustrania dissimile is shallow and directed backwardly. The dental pattern in Bustrania can be very similar to that in Pseudocricetodon, but the enamel in the former extends much more onto the base of the teeth than in the latter.

Material and measurements: Table 4, Figs. 2a-c, 3a-c, 8, and 9

Bustrania dissimile is so abundant in Buštranje that we decided to study and measure the specimens collected in 2013 only.

\section{Description}

M1: The anterocone is incorporated into a wide anteroloph. In the majority of the specimens there is a notch between the labial branch of the anteroloph and the paracone; in others the lingual and labial branches of the anteroloph are connected to the protocone and paracone respectively. The anterior arm of the protocone is complete in $5 / 78$ and connected to the anterocone, incomplete in 63/78 and absent in 10/78 of the unworn M1. Except in the aberrant M1 (Fig.8d), the protolophule and metalophule are directed slightly forward and insert on the anterior side of the protocone and hypocone. The posterior arm of the protocone is strong, reaches the hypocone and determines the shape of the sinus. There is an array of low cusps and ridges in the central basin of the majority of the fresh M1. The posteroloph is about the same height as the metalophule and reaches the metacone. The occlusal surface of worn specimens is almost flat. The M1 has three roots. M2: The long labial branch of the anteroloph is connected to the base of the paracone. The lingual branch is much weaker and continues as a low cingulum to the base of the hypocone. The position of the short anterolophule is at the level of the
Fig. 9 Bustrania dissimile nov. gen. nov. sp. from Buštranje (031). a m1 (BUS-1054). b m1 (BUS-1114). $\mathbf{c ~ m 1 ~ ( B U S - 1 0 5 0 ) . ~ d ~ m 1 ~ ( B U S - 1 1 0 3 ) . ~ e ~}$ $\mathrm{m} 1$ (BUS-1124). f-g m1 (BUS-1043). h m2 (BUS-1160). i m2 (BUS1165). j m2 (BUS-1172). $\mathbf{k}$ m2 (BUS-1197). 1 m2 (BUS-1125). $\mathbf{m}-\mathbf{n}$ m2 (BUS-1154). o m3 (BUS-1231). p m3 (BUS-1275). q m3 (BUS-1243). $\mathbf{r}$ m3 (BUS-1273). $\mathbf{s}$ m3 (BUS-1290). t-u m3 (BUS-1259)

labial outline of the protocone. The parallel protolophule and metalophule are complete and slightly anterolingually directed, inserting on the anterior corners of the protocone and hypocone respectively. The strong posterior arm of the protocone determines the shape of the posteriorly directed sinus. There is an array of short low lophs and cusps within the central basin that cannot be homologized with the structural elements of later cricetids. Some specimens show a small protoconule and/or metaconule and a few M2 have a small mesostyle. The long posteroloph reaches the base of the metacone in some M2, but is separated from the metacone by a notch in others.

A for cricetids very peculiar structural element in the M2 of Bustrania dissimile is the occasional presence of a small cusp in the valley between the labial arm of the anteroloph and the protolophule or between the metalophule and the posteroloph (Fig. 8k). The occlusal surface of worn specimens is almost flat. The M2 has three roots.

M3: The labial branch of the anteroloph is well developed and reaches the paracone, but the lingual branch is weak or absent. The straight protolophule is either transverse or directed slightly forward. The sinus is very shallow and the hypocone and metacone are incorporated into the posteroloph. The posterior part of the M3 is reduced, so the metalophule is either short, incomplete or absent. The occlusal surface becomes flat in worn specimens. The M3 has three roots.

m1: The "anteroconid" is in many specimens limited to a labially directed spur of the metaconid, but in others there is a tiny cusp at the end of a short anterolophulid. A true metalophulid 1 is missing, but the short metalophulid 2 is complete. The position of the metaconid relative to the protoconid is rather far forward and this cusp is connected to the entoconid by a ridge of variable height along the lingual margin of the occlusal surface. The hypolophulid is slightly posteriorly directed and inserts on the hypoconid. There are one, two or three low short transverse ridges in the central basin of most $\mathrm{m} 1$, but in some there are just irregular low accessory cusps in that position. The strong and curved posterolophid reaches the entoconid. In many $\mathrm{m} 1$, an irregular ridge is present in the basin between the hypolophulid and the posterlophid; this could be a remnant of the posterior arm of the hypoconid as in Fig. 9f. The occlusal surface becomes flat through wear. The $\mathrm{m} 1$ has two roots.

m2: The $\mathrm{m} 2$ has about the same length as the $\mathrm{m} 1$, but is wider. The lingual arm of the anterolophid is longer than the labial arm and connected to the metaconid. The anterolophulid, 
a

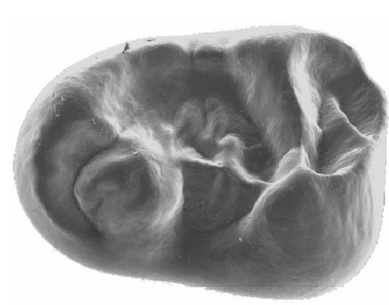

$\underline{b}$

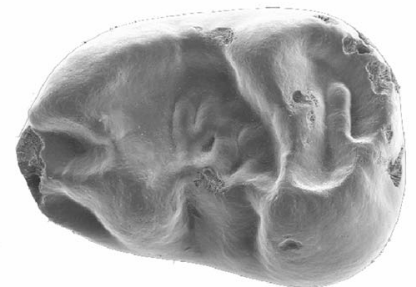

C

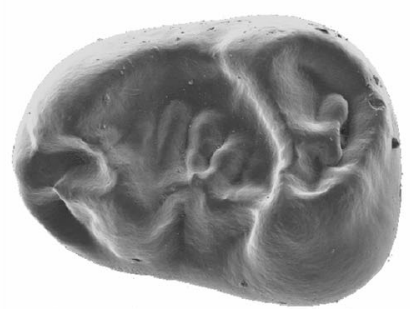

d

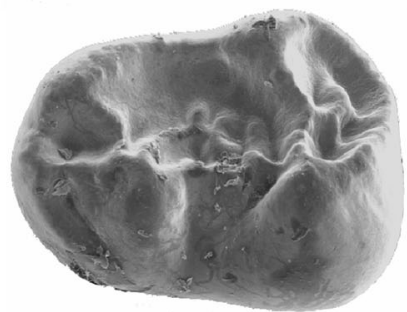

e
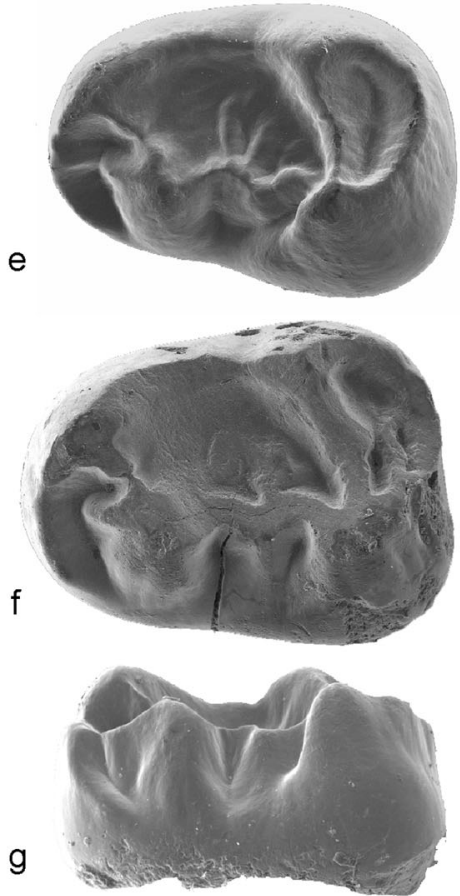

h
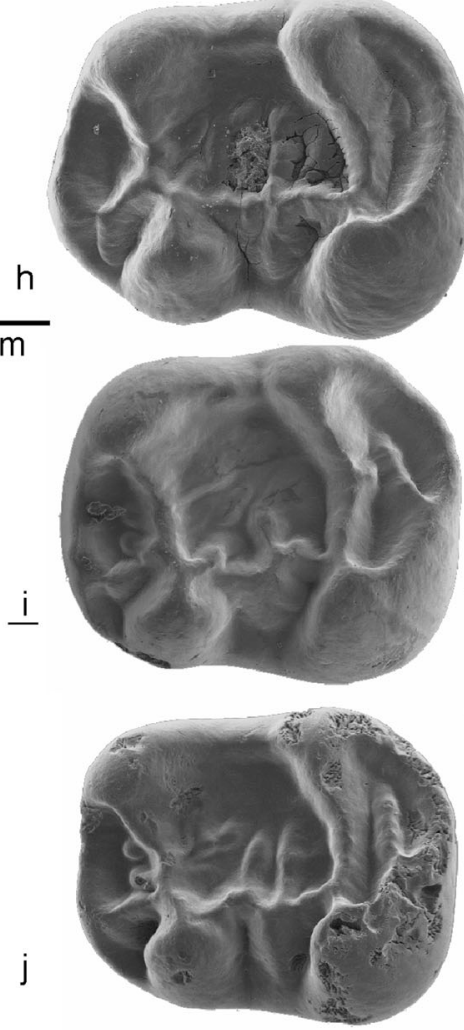

k
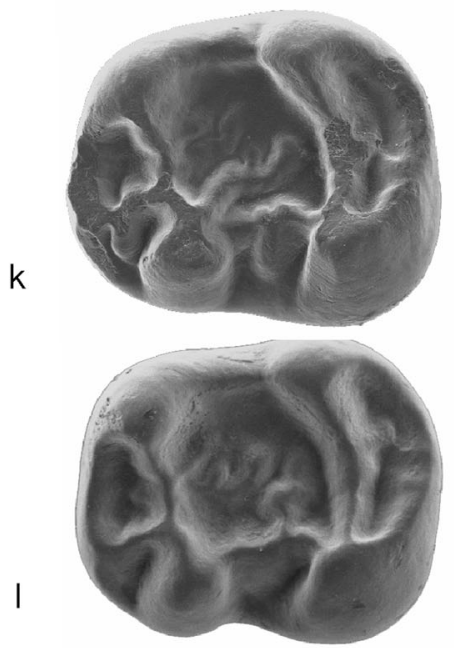

m

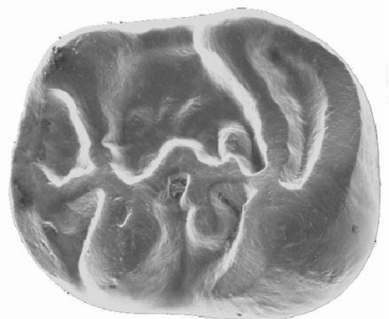

n

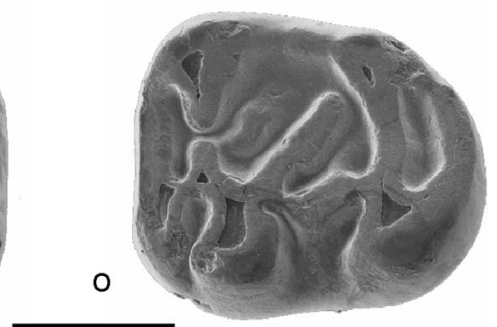

$0.5 \mathrm{~mm}$
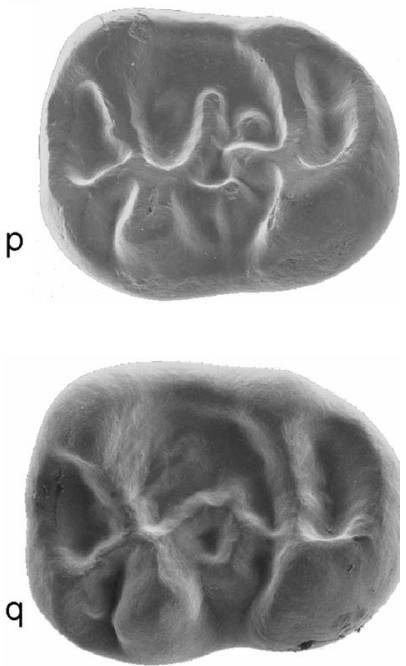

s
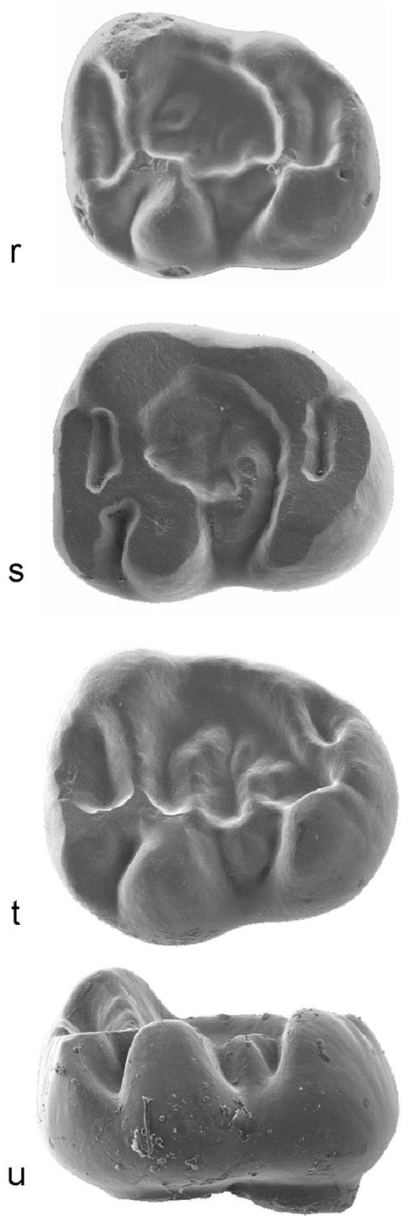
Table 4 Measurements of the cheek teeth of Bustrania dissimile nov. sp. from the type locality Buštranje

\begin{tabular}{|c|c|c|c|c|c|c|}
\hline \multirow[t]{2}{*}{ Buštranje } & \multicolumn{3}{|c|}{ Length (mm) } & \multicolumn{3}{|c|}{ Width (mm) } \\
\hline & Range & Mean & $\mathrm{N}$ & Range & Mean & $\mathrm{N}$ \\
\hline M1 & $1.20-1.44$ & 1.34 & 94 & $0.84-1.06$ & 0.97 & 96 \\
\hline M2 & $0.97-1.21$ & 1.07 & 102 & $0.87-1.13$ & 0.98 & 101 \\
\hline M3 & $0.76-0.97$ & 0.86 & 70 & $0.73-1.01$ & 0.86 & 70 \\
\hline $\mathrm{m} 1$ & $1.01-1.24$ & 1.12 & 107 & $0.73-0.92$ & 0.82 & 107 \\
\hline $\mathrm{m} 2$ & $1.00-1.22$ & 1.12 & 79 & $0.82-1.06$ & 0.92 & 80 \\
\hline $\mathrm{m} 3$ & $0.95-1.22$ & 1.03 & 73 & $0.72-0.97$ & 0.83 & 72 \\
\hline
\end{tabular}

which bears a labial spur in some $\mathrm{m} 2$, delimits an anterosinusid. The parallel metalophulid and hypolophulid are slightly curved, posteriorly directed and insert on the anterior parts of the protoconid and hypoconid respectively. There may be one, two, three or even four short, low ridges within the central basin and some $\mathrm{m} 2$ have an ectomesolophid also. The posterolophid connects the hypoconid to the entoconid.

In many $\mathrm{m} 2$, an irregular ridge is present in the basin between the hypolophulid and the posterlophid (Fig. $9 \mathrm{i},-$ j, $-\mathrm{k}$ ), it could be a remnant of the posterior arm of the hypoconid as in Fig. 9j. The $\mathrm{m} 2$ has two roots and the occlusal surface of worn specimens is almost flat.

m3: The majority of the $m 3$ are only slightly shorter than the $\mathrm{m} 2$; they are not much reduced and similar in dental pattern. The anterosinusid is quite well developed in most $\mathrm{m} 3$, but may be absent. Many specimens have a small anteroconid where the anterolophulid meets the anterolophid. The number of low, short ridges in the main basin varies between zero and three. In a few, the anterior-most of these ridges is developed as the posterior arm of the protoconid (Fig. 9o). The posterior arm of the hypoconid is absent. The occlusal surface becomes flat through wear. The $\mathrm{m} 3$ has two roots.

The microstructure of the enamel

Lower incisor (Fig. 4a-c): The outer surface of the very thin $(\sim 60 \mathrm{um})$ enamel is smooth and reaches rather far laterally. The PI consists of transverse uniserial HSB that make an angle of about 25 degrees with the normal on the EDJ. The PE consists of radial enamel and is somewhat thinner than the PI. The PLEX is absent.

Molars (Figs. 10a-c and 11a-d): The enamel of the sectioned Bustrania dissimile $\mathrm{m} 2$ shows a ring of poorly developed lamellar enamel that is restricted to the lateral side of the
Fig. 10 a Transverse section of the $\mathrm{m} 2$ of Bustrania dissimile nov. sp. From Buštranje. $\mathbf{b}$ detail of a. $\mathbf{c}$ detail of $b$

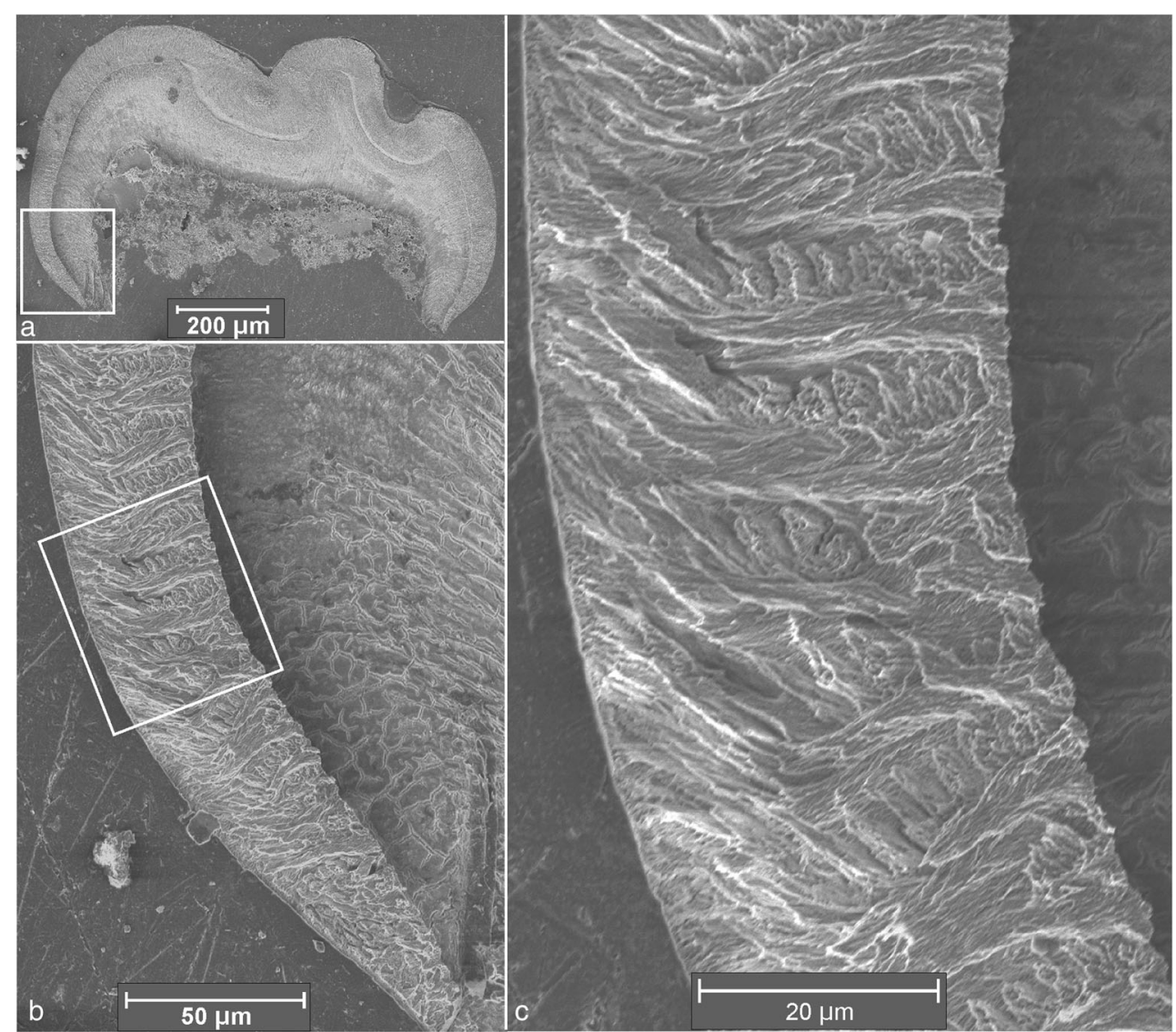


crown and has thus to be classified as intermediate between type-P and C (Koenigswald 2004). The longitudinal section of a M1 (Fig. 11) shows that a thin layer of radial enamel continues all the way to the base of the roots of the molar. In contrast the inner portion of the enamel of the anterocone of the M1 consists of well-developed lamellar enamel. This suggests that the anterocone of this very small M1 was subjected to considerable vertical biomechanical stress (Koenigswald 2004). The differences in the distribution of enamel types between the $\mathrm{m} 2$ and $\mathrm{M} 1$ and the lamellar enamel restricted to the anterocone suggests that the distribution of enamel types in molars may be more complex than Koenigswald (2004) assumed.

\section{Conclusions}

The morphology of the cheek teeth and the microstructure of the enamel of the lower incisor of Witenia europea show about the same stage of evolution as the earliest murid, Pappocricetodon antiquus, from the Middle
Eocene of the Jiangsu province (China), but the enamel of the molars is more primitive. Most surprisingly, this murid with very primitive dental features occurs in the (? late) Eocene locality Buštranje not only associated with the somewhat less primitive Bustrania dissimile, but also with fully developed species of Paracricetodontinae, Melissiodontinae and Pseudocricetodontinae (Table 1). This combination of murids showing very different stages of evolution in the same assemblage is so far unique, but shows the weakness of biostratigraphical conclusions based on a few taxa only.

Including the genera Witenia and Bustrania into the Pappocricetodontinae makes this subfamily polyphyletic. It assembles genera that share a primitive dental morphology, but do not represent one clade. Inclusion into the Pappocricetodontinae of Witenia europea and Bustrania dissimile, two species from the same locality that differ in size, dental pattern, the relative size of the molars and even microstructure of the enamel of the lower incisor confirms the polyphyletic status of the current Pappocricetodontinae concept. Unfortunately the present knowledge of the early history

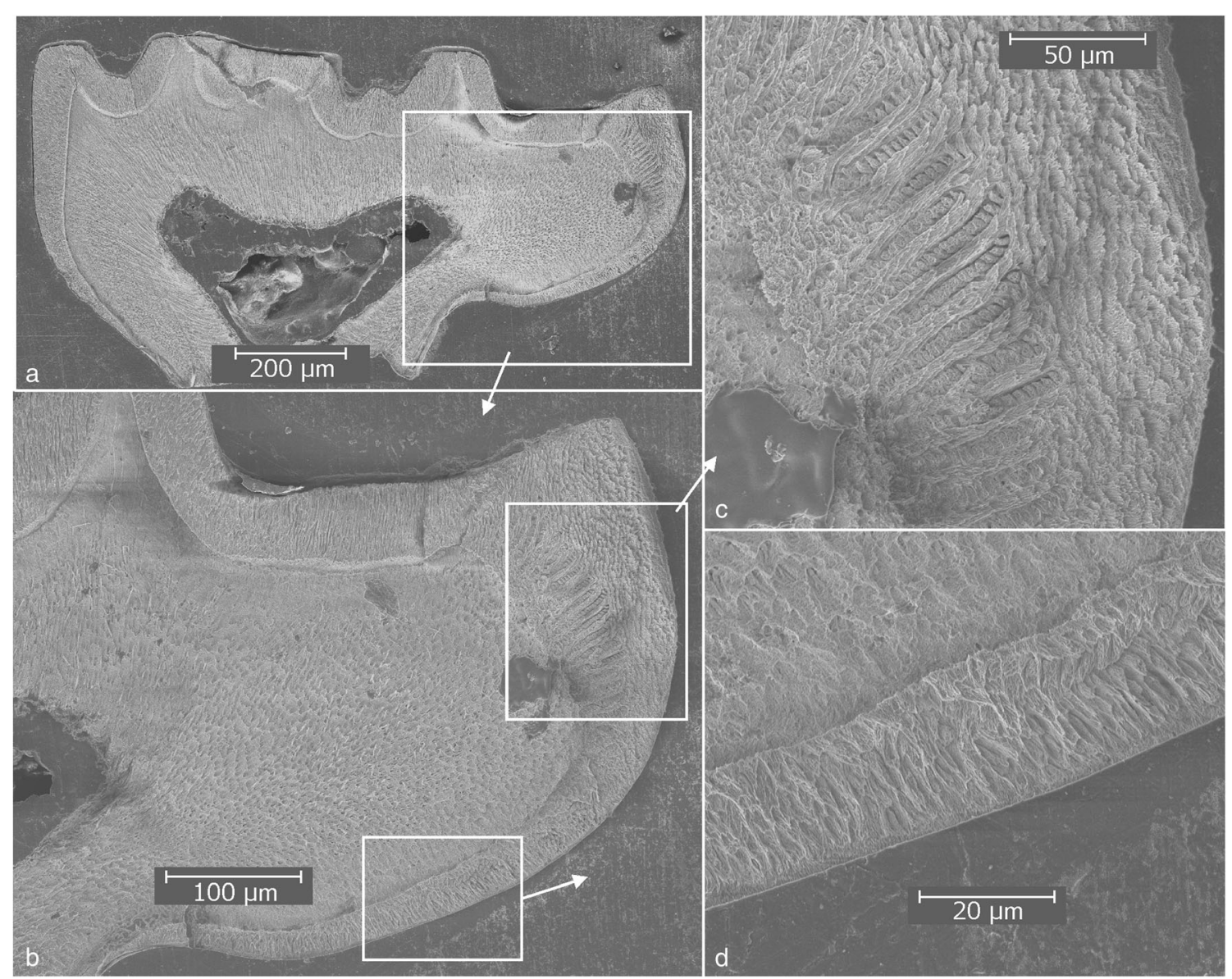

Fig. 11 a Longitidinal section of the M1 of Bustrania dissimile nov. sp. from Buštranje, front end to the right. b detail of a. c detail of b (upper part). d detail of $b$ (lower part) 
of the Muridae does not allow the recognition of clades among the primitive Eocene cricetids.

Acknowledgements We gratefully acknowledge the facilities offered during our fieldwork by Jovan Stojanović and the staff of motel Nina (Babušnica) and by Mile Ilić at the premises of the old mill of Ljuberadja. Without the intelligent support in the field of Miloš Milivojević life would have been entirely different and the number of collected fossils much lower. The SEM pictures of the incisor enamel were made by Hans Meeldijk and those of the cheek teeth by Tilly Bouten (both Utrecht University). Helder Gomes Rodrigues is thanked for the original photographs of Witenia yolua. The paper benefitted from the remarks, additions and improvements suggested by an anonymous reviewer and Larry Flynn.

Funding information The field work has been supported financially by the Museum of Natural History of Beograd and by the Hans de Bruijn Foundation.

\section{Compliance with ethical standards}

Conflict of interest The authors declare that they have no conflict of interest.

Open Access This article is distributed under the terms of the Creative Commons Attribution 4.0 International License (http:// creativecommons.org/licenses/by/4.0/), which permits unrestricted use, distribution, and reproduction in any medium, provided you give appropriate credit to the original author(s) and the source, provide a link to the Creative Commons license, and indicate if changes were made.

\section{References}

Bergqvist, L. P., \& von Koenigswald, W. (2017). The dentition of Carodnia vieirai (Mammalia: Xenungulata): enamel microstructure and mastication pattern. Palaeontologia Electronica, 20.2(30A), 1-15.

Bowdich, T. E. (1821). An analysis of the natural classifications of mammalia, for the use of students and travellers. Paris: J. Smith.

Bruijn, H. de., Ünay, E., Saraç, G., \& Yïlmaz, A. (2003). A rodent assemblage from the Eo/Oligocene boundary interval near Süngülü, Lesser Caucasus, Turkey. Coloquios de Paleontología, 1, 47-76.

Bruijn, H. de., Marković, Z., Wessels, W., Milivojević, M., \& Weerd, A. A. van de (2018). Rodent faunas from the Paleogene of south-east Serbia. Palaeobiodiversity and Palaeoenvironments, 98(3), 441485.

Daxner-Höck, G. (2000). Ulaancricetodon badamae n. gen. n. sp. (Mammalia, Rodentia, Cricetidae) from the valley of lakes in Central Mongolia. Paläontologische Zeitschrift, 74, 215-225.

Emry, R. J., Tyutkova, L. A., Lucas, G. L., \& Wang, B. (1998). Rodents of the middle Eocene Shinzhaly fauna of Eastern Kazakhstan. Journal of Vertebrate Paleontology, 18(1), 218-227.
Freudenthal, M., Hugeney, M., \& Moissenet, E. (1994). The genus Pseudocricetodon (Cricetidae, Mammalia) in the Upper Oligocene of the province of Teruel (Spain). Scripta Geologica, 104, 57-114.

Gomes Rodrigues, H., Marivaux, L., \& Vianey-Liaud, M. (2012). The Cricetidae (Rodentia, Mammalia) from Ulantatal area (Inner Mongolia, China): new data concerning the evolution of Asian cricetids during the Oligocene. Journal of Asian Earth Sciences, 56, 160-179. https://doi.org/10.1016/j.jseaes.2012.05.007.

Gomes Rodrigues, H., Marivaux, L., \& Vianey-Liaud, M. (2014). Rodent paleocommunities from the Oligocene of Ulantatal (Inner Mongolia, China). Palaeovertebrata, 8, 1-11.

Illiger, C. (1811). Prodromus systematis mammalium et avium additis terminis zoographicis utriusque classis, eorumque versione germanica (pp. 1-301). Berolini: Sumptibus C. Salfeld.

Kalthoff, D. C. (2000). Die Schmelzmicrostructur in den Incisiven der hamsterartigen Nagetiere und anderer Myomorpha (Rodentia, Mammalia). Palaeontographica, Abteilung A, 269, 1-193.

Kalthoff, D. C. (2006). Incisor enamel microstructure and its implications to higher-level systematics of Eurasian Oligocene and Early Miocene hamsters (Rodentia). Palaeontographica, Abteilung A, 277(1-6), 67-81.

Koenigswald, W. von (2004). The three elementary types of schmelzmuster in rodent molars and their occurrence in the various rodent clades. Palaeontographica A, 270, 95-132.

López-Guerrero, P., Maridet, O., \& Daxner-Höck, G. (2017). Cricetidae (Rodentia, Mammalia) from the Oligocene of the Valley of Lakes (Mongolia): the genera Aralocricetodon, Eocricetodon, Bagacricetodon, Witenia and Paracricetodon. Palaeobiodiversity and Palaeoenvironments, 97, 93-109. https://doi.org/10.1007/ s12549-016-0266-8 .

Marković, Z., Wessels, W., Weerd, A. A., van de \& Bruijn, H. de (2018). On a new Diatomyid (Rodentia, Mammalia) from the Paleogene of south-east Serbia, the first record of the family in Europe. Palaeobiodiversity and Palaeoenvironments, 98(3), 459-469.

Tong, Y. (1992). Pappocricetodon, a pre-Oligocene cricetid genus (Rodentia) from central China. Vertebrata PalAsiatica, 30, 1-16.

Tong, Y. (1997). Middle Eocene small mammals from Liguanqiao basin of Henan province and Yuanqu basin of Shanxi province, Central China. Palaeontologica Sinica, 18(New Series C (26)), 1-256.

Wang, B., \& Dawson, M. R. (1994). A primitive cricetid (Mammalia: Rodentia) from the middle Eocene of Jiangsu Province, China. Annals of Carnegie Museum, 63, 239-256.

Weerd, A. A. van de., Bruijn, H., de Marković, Z., \& Wessels, W. (2018). Paracricetodontinae (Mammalia, Rodentia) from the late Eocene and Early Oligocene of south-east Serbia. Palaeobiodiversity and Palaeoenvironments, 98(3), 489-508.

Wessels, W., Marković, Z., Weerd, A. A.van de., \& Bruijn, H. de (2018). New Melissiodontinae (Mammalia, Rodentia) from the Paleogene of south-east Serbia. Palaeobiodiversity and Palaeoenvironments, 98(3), 471-487. 